\title{
El desarrollo de la vida \\ ante la pandemia de COVID-19
}

Libia Yanelli Yánez Peñúñuri, Susana Angélica Pastrana Corral,

Cuitláhuac Morales Hernández y Linda Isis García Estrada (COORDINADORES)
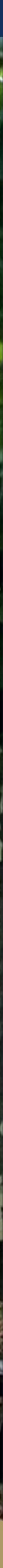

\section{Qartuppi}




\section{El desarrollo de la vida ante la pandemia de COVID-19}

Libia Yanelli Yánez Peñúñuri, Susana Angélica Pastrana Corral, Cuitláhuac Morales Hernández y Linda Isis García Estrada (COORDINADORES)

Qartuppi 


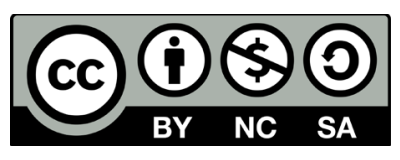

Esta obra se edita bajo una Licencia Creative Commons

Atribución-NoComercial-CompartirIgual 4.0 Internacional.

El desarrollo de la vida ante la pandemia de COVID-19

1era. edición, diciembre 2021

ISBN 978-607-8694-24-2

DOI 10.29410/QTP.21.22

D.R. (C) 2021. Qartuppi, S. de R.L. de C.V.

Villa Turca 17, Villas del Mediterráneo

Hermosillo, Son. 83220 México

http://www.qartuppi.com

Edición y diseño: Qartuppi, S. de R.L. de C.V.

Fotografía de portada: León Felipe Irigoyen 
In memoriam

Cuitláhuac Morales Hernández

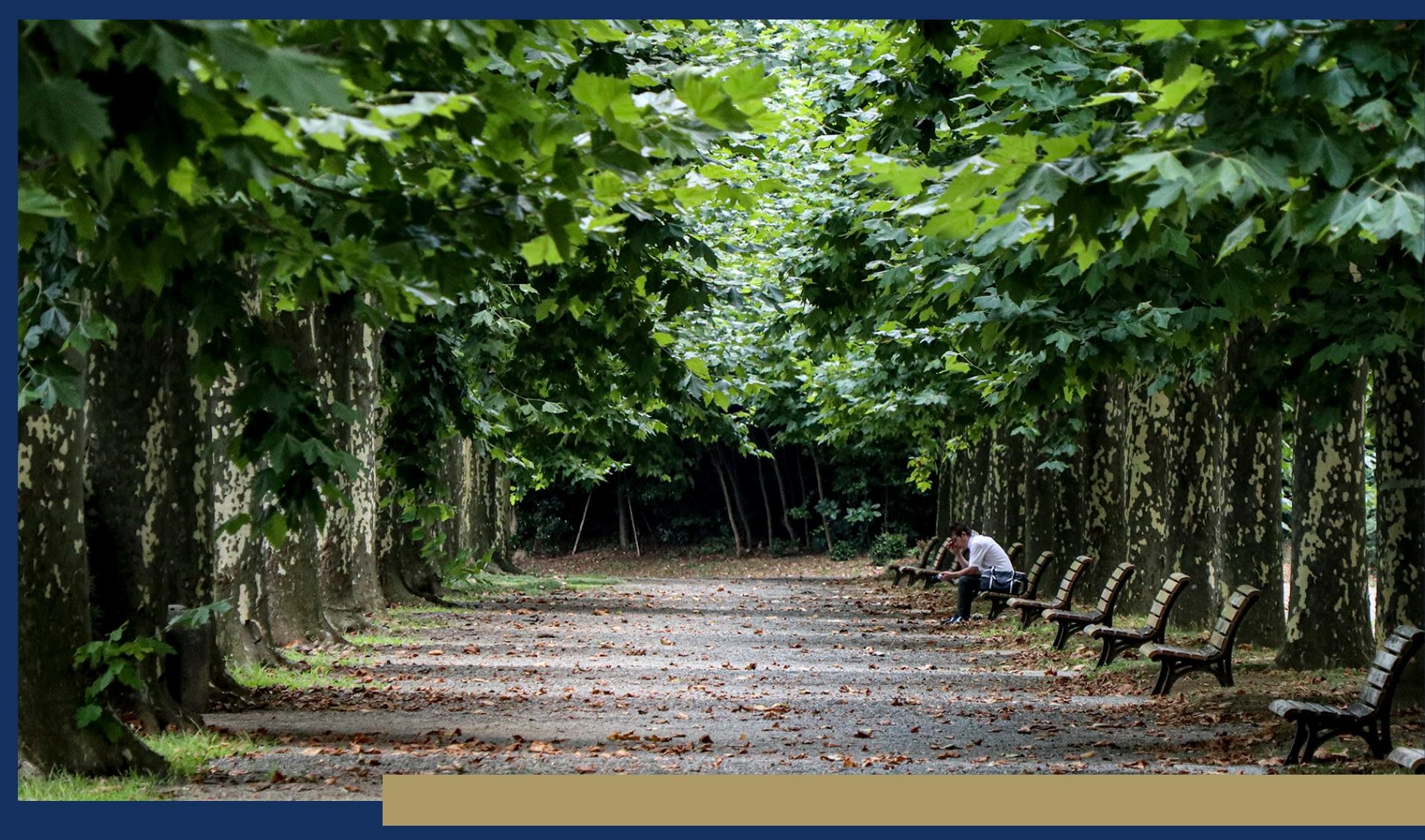




\section{Agradecimientos}

Nuestro más sincero agradecimiento a la Academia de Metodología de Estudios Sociales del Departamento de Ciencias Sociales de la Universidad de Sonora, Campus Caborca, por promover el trabajo colegiado entre sus miembros, por generar sus aportes y conocimientos plasmados en los capítulos del presente libro.

A la Universidad de Sonora por su apoyo y patrocinio para poder realizar esta obra.

A los revisores, por las sugerencias que enriquecieron el documento final.

A los investigadores que plasmaron en cada uno de los capítulos de esta obra, su empeño y dedicación. 


\section{Tabla de contenido}

Libia Yanelli Yánez Peñúñuri, Susana Angélica Pastrana Corral, Cuitláhuac Morales Hernández y Linda Isis García Estrada

\section{Capítullo 1}

Aspectos generales de la COVID-19

Cuitláhuac Morales Hernández, Libia Yanelli Yanez Peñuñuri

y Linda Isis García Estrada

Capítulo 2

Funcionamiento familiar: evaluación de obstructores en tiempos de COVID-19

Jorge Arturo Martínez Gómez, Yolima Bolivar Suárez

y María Nancy Mendoza Bautista 


\section{Capítulo 4}

Exposición de violencia por conflictos armados (narcotráfico) y estrés postraumático en la pandemia de COVID-19

Alexia Maytee Campas Urías, Libia Yanelli Yanez Peñuñuri y Marcela Cáñez Navarrete

Capítulo 5

Factores que influyen en las alteraciones de sueño durante la pandemia de COVID-19

Linda Isis García Estrada

65

Capítulo 6

Ensayo sobre la muerte y la COVID

Ignacio Alberto Valdez Bernal 


\section{Prólogo}

La Organización Mundial de la Salud (OMS) emitió, en diciembre de 2019, un informe del nuevo virus SARS-CoV-2; este brote surgió en la ciudad de Wuhan, China. Los signos y síntomas más comunes son fiebre, tos seca, congestión nasal, pérdida del olfato y gusto, transmitiéndose por contacto de persona a persona. Luego de expandirse en varios países, el 30 de enero de 2020, la OMS declaró una emergencia de salud pública de importancia internacional (ESPII) y el 11 de marzo, por su alto nivel de propagación, consideró a la enfermedad COVID-19 como pandemia; por lo que, el director general de la OMS hizo un llamado a los países a adoptar medidas urgentes y agresivas. Unas de las medidas adoptadas fue el confinamiento y el distanciamiento social.

El aislamiento prolongado tuvo efectos negativos en las personas, por el miedo o la incertidumbre del nuevo virus. Las pérdidas humanas, el dolor sin una despedida habitual, la separación física de nuestros seres queridos y los efectos económicos (e. g., cierre de empresas, pérdida de empleo) tuvieron un impacto en la salud mental como, por ejemplo, una mayor incidencia de trastornos mentales y manifestaciones emocionales, promoviendo síntomas de estrés, ansiedad y depresión.

Además de las afectaciones de salud física y mental, hubo un incremento de la violencia y del desempleo. Y, en el caso de la población infanto-juvenil, el cierre de las instituciones educativas afectó su aprendizaje y se incrementó la deserción escolar y la desigualdad.

Considerando lo anterior, la Academia de Metodología y Estudios Sociales de la Unidad Regional Norte, campus Caborca, de la Universidad de Sonora promovió entre sus miembros la realización de investigaciones y ensayos acerca del desarrollo de la vida durante la pandemia de COVID-19 y el impacto en ámbitos como la educación, la familia, la salud mental, la violencia, la calidad de sueño y la muerte. 
El presente libro compila diversos capítulos desarrollados por integrantes de dicha academia y estudiantes del Programa de Psicología. En el primer capítulo, Cuitláhuac Morales Hernández, Libia Yanelli Yanez Peñuñuri y Linda Isis García Estrada analizan los aspectos generales de la COVID-19, la prevalencia de casos confirmados y los decesos a causa de dicha enfermedad en diferentes etapas del desarrollo humano.

En el segundo capítulo, Jorge Arturo Martínez Gómez, Yolima Bolivar Suárez y María Nancy Mendoza Bautista abordan el funcionamiento familiar en tiempos de COVID-19 y los problemas enfrentados como el aislamiento social, la falta de recursos para adaptarse a nuevos conceptos, así como los problemas económicos, laborales, académicos y sanitarios.

Libia Yanelli Yanez Peñuñuri, en el tercer capítulo, presenta el efecto de la infodemia en la salud mental y analiza los efectos del exceso de información en las redes sociales y la tecnología, impactando en la generación de estereotipos y discriminación hacia las personas de origen asiático, el aumento de la incertidumbre, el miedo y los comportamientos sociales negativos en la población.

En el cuarto capítulo, Alexia Maytee Campas Urias, Libia Yanelli Yanez Peñuñuri y Marcela Cáñez Navarrete estudian la exposición de violencia por conflictos armados (narcotráfico) y su relación con el trastorno de estrés postraumático durante la pandemia de COVID-19, en jóvenes estudiantes de Caborca, Sonora, México.

Linda Isis García Estrada, en el quinto capítulo, expone los factores que influyen en las alteraciones de sueño durante la pandemia de COVID-19 y las repercusiones negativas en el número de horas de sueño, a partir de los cambios de rutina por el confinamiento, lo que puede generar síntomas de ansiedad, estrés y depresión.

En el sexto capítulo, Ignacio Alberto Valdez Bernal presenta un ensayo sobre la muerte, a partir de una reflexión psicológica y filosófica del proceso de morir durante la pandemia de COVID-19 y el significado de la vida.

Sin duda alguna, la pandemia de COVID-19 vino a transformar las actividades laborales, escolares, sociales y familiares, bajo una campana de incertidumbre, ansiedad, angustia, desesperación y depresión, que lamentablemente ha cobrado vidas humanas; durante lo más crítico de esta terrible pandemia, hemos aprendido a aprender y desaprender conceptos como resiliencia, tolerancia, lo colectivo por la individualidad y, en resumen, la aceptación al cambio con todo lo que ello conlleva. 


\section{Capítulo 1}

\section{Aspectos generales de la COVID-19}

Cuitláhuac Morales Hernández, Libia Yanelli Yanez Peñuñuri

y Linda Isis García Estrada

La COVID-19 es una enfermedad infecciosa causada por el virus SARS-CoV-2. Los síntomas más frecuentes debido a este virus son fiebre, tos seca, dificultad para respirar, diarrea, náuseas y pérdida de gusto y olfato - siendo la pérdida de olfato, típica en la primera etapa de la enfermedad-, además, pueden presentarse síntomas menos típicos como rinorrea aislada o dolor de cabeza. Un cuadro grave de la COVID-19 se caracteriza por hipoxia o requerimiento de oxigenación (Huamán-Saavedra, 2020; Llover \& Jiménez, 2021; Organización Mundial de la Salud [OMS], 2020).

Esta enfermedad apareció por primera vez en la ciudad de Wuhan, China, en la provincia de Hubei, en el mes de diciembre de 2019. Posteriormente, el 11 de marzo de 2020, la OMS decretó una alerta por COVID-19, declarándola una pandemia y un problema de salud pública a nivel internacional (Apaza et al., 2020; Ciotti et al., 2020; HuarcayaVictoria, 2020; Ramos, 2020).

Al 22 de octubre de 2021, a nivel internacional, se confirmaron 242796813 casos de COVID-19 (Center for Systems Science and Engineering, 2021). Asimismo, los cinco países con mayor número de infectados de COVID-19 han sido:

1. Estados Unidos (46 175 122)

2. India (34 143236 )

3. Brasil (21 697 341)

4. Reino Unido (8 641 221)

5. Rusia (8 168 305) 
Además, los países con mayor número de muertes a causa de COVID-19 son:

1. Estados Unidos (753 749)

2. Brasil (604 764)

3. India (453 076)

4. México (285 669)

5. Rusia (228 453)

De acuerdo con la OMS (2021), actualmente, existen cuatro variantes de COVID-19 que generan gran incertidumbre. A continuación, se presenta su denominación y los países donde se documentaron las primeras muestras:

- Alfa (Reino Unido)

- Beta (Sudáfrica)

- Delta (India)

- Gamma (Brasil)

Una de las variantes más contagiosas, identificada hasta hoy, es la variante delta. Esta se ha dispersado en 182 países y alcanzó el 82.2\% del total de los casos reportados en Estados Unidos (Fernández, 2021). Asimismo, en Canadá se han reportado personas infectadas con dicha variante, la cual provoca mayor riesgo de requerir cuidados intensivos y mayor riesgo a la muerte (Fisman \& Tuite, 2020).

Por otra parte, el confinamiento y los cambios de rutina debidos a la pandemia de COVID-19 han obligado a la población a adaptarse y emplear el tiempo de forma diferente (Fondo de las Naciones Unidas para la Infancia [UNICEF], 2020a). Otros de los aspectos que ha interferido en los individuos ha sido la separación de familias y amigos, la pérdida de la libertad, el miedo al contagio, la falta y exceso de información, lo cual ha impactado en la salud física y mental en trabajadores sanitarios y población general (Gómez, 2021; Gould et al., 2021).

La pandemia de COVID-19 no solo ha causado daños a la salud (Atamari-Abahui et al., 2021), sino que ha paralizado la economía, afectando a diversos sectores productivos como el turismo y el comercio (Clavellina, 2020; Quiroz Carrillo et al., 2020). Asimismo, ha afectado aspectos sociales, medioambientales, económicos y, también, educativos, con el cierre de instituciones (Vásquez et al., 2020). 


\section{La COVID-19 en diferentes etapas del desarrollo}

\section{Niños y adolescentes}

En general, los síntomas más comunes de COVID-19 en niños incluyen fiebre, tos, vómito, diarrea y rinorrea. Algunos autores señalan que la mayoría de los casos de niños infectados de COVID-19 no presentan síntomas de forma grave como los adultos y, en algunos casos, no presentan síntomas (Mallapaty, 2021). No obstante, en Colombia, un estudio refirió que el 50\% de los niños que se encontraban infectados de COVID-19 presentaron fiebre, al igual que los adultos fueron las mismas cargas virales, lo cual aumentó la preocupación de especialistas. En la misma línea, en Estados Unidos, aun cuando la tasa de mortalidad en niños es menor del 1\%, la gravedad de las consecuencias o secuelas que puede causar la COVID-19 en los niños ha ido en incremento, como el síndrome inflamatorio multisistémico, que puede dañar el sistema digestivo, nervioso, respiratorio y el corazón (Deville et al., 2021; López et al., 2020).

En México, en un estudio en niños de 0 a 17 años, se registró un total de 5733 (4.2\%) casos confirmados de COVID-19 en menores de edad en la Ciudad de México, confirmados por la Secretaría de Salud; los niños más afectados fueron los del grupo de 15-17 años (31.6\%), seguido del grupo de 0-2 años (15.3\%), de 9-11 años (13.9\%), de 6-8 año $(10.7 \%)$ y de $3-5$ años $(8.8 \%)$, registrando síntomas como tos, cefaleas, fiebre, entre otros. Con una mortalidad del 1.3\%, ocurriendo casi la mitad de las muertes en menores de 2 años, identificando factores de riesgo como diagnóstico de neumonía, obesidad, hipertensión, diabetes, enfermedades pulmonares crónica y patología renal (Wong-Chew et al., 2021).

La COVID-19 ha afectado la salud física y mental en niños y adolescentes. En un sondeo realizado por la UNICEF (2020b), en adolescentes y jóvenes (13-29 años) de Latinoamérica y el Caribe en nueve países, el 27\% de los participantes reportaron sentir ansiedad y el 15\% depresión, en los últimos siete días, influyendo el 30\% de sus emociones por la situación económica; el 46\% informó menos motivación para realizar actividades que antes disfrutaban y el $36 \%$ se siente menos motivado para realizar sus actividades; asimismo, el 73\% siente la necesidad de pedir ayuda para su bienestar físico y mental. Además, en Colombia se aplicó el instrumento de "Percepción de Riesgo Frente al Covid-19" en adolescentes entre 13 y 18 años, estudiantes de cinco instituciones, siendo el 50.3\% mujeres; se identificó que el 70\% de los participantes percibe a la COVID-19 como 
un riesgo medio a alto, y sienten temor a morir o enfermarse gravemente, especialmente si la contrae un familiar; esto afecta su salud mental, generando ansiedad o depresión (Rosero et al., 2021).

En México, se llevó a cabo la Encuesta Nacional de Ocupación y Empleo (ENOE) y la Encuesta Telefónica de Ocupación y Empleo (ETOE) en adolescentes de 12 a 18 años, reportando horas reducidas al estudio (35\%), más en el grupo de jóvenes de 12 a 14 años en comparación del grupo de 15 a 18 años; similar en hombre y mujeres, siendo mayor para aquellos adolescentes en zonas rurales que en zonas urbanas. Se observa una afectación en el aprendizaje, derivado del cierre de las instituciones educativas por la pandemia de COVID-19; además, de acuerdo con la Secretaría de Educación Pública (SEP), la cifra de deserción en educación básica es del 10\% (Parker, 2020).

\section{Jóvenes y adultos}

Durante la pandemia, se ha observado un aumento de casos de COVID-19 en adultos jóvenes. En ese sentido, en un estudio llevado a cabo en pacientes adultos jóvenes hospitalizados por COVID-19 de edades entre 18 y 35 años, se encontró que el 92\% presentó una o más comorbilidades, el 38\% de los pacientes presentó antecedentes familiares de hipertensión arterial o diabetes mellitus y el 26\% tenía hábitos nocivos; además, respecto al ingreso de los pacientes al hospital, el 58\% presentaba saturación de oxígeno, el 30\% ingresó a ventilación mecánica y el 10\% falleció (Salcedo-Matienzo et al., 2020).

De acuerdo con el Instituto Nacional de Salud en Colombia, de los primeros $100 \mathrm{ca}$ sos de fallecimientos de COVID-19, 63 eran del sexo masculino, la mayoría con patología como hipertensión arterial (35\%), diabetes mellitus (21\%), enfermedades cardiovasculares y cerebrovasculares (19\%), enfermedad pulmonar obstructiva crónica (16\%), obesidad $(12 \%)$, tabaquismo (9\%) y patología tiroidea (8\%). Asimismo, el 10\% de los pacien-

tes fallecidos eran menores de 60 años y no presentaban comorbilidad (Marín-Sánchez, 2020).

La mayoría de las muertes por COVID-19 en México, se produce en una institución pública (90\%), además, dos hombres por cada mujer han fallecidos; según la distribución de edad de las personas que fallecieron, el 63\% tenía entre 40 y 69 años y el 6\% era menor de 40 años; entre las entidades con altos niveles de mortalidad se encontraban: Tabasco, Ciudad de México, Sinaloa, Baja California, Sonora, Quintana Roo y Campeche 
(Hernández, 2021). Otro estudio realizado en México reportó que los adultos jóvenes con COVID-19, que ameritaban hospitalización, tenían un alto porcentaje de obesidad similar a los adultos mayores de 35 años, pero los cuadros de la enfermedad eran menos letales comparados con los enfermos adultos hospitalizados (Sánchez-Ríos et al., 2021).

Respecto a los indicadores de salud mental en adolescentes y jóvenes durante la pandemia, algunos autores refieren que el confinamiento obligatorio ha tenido repercusiones negativas sobre salud mental y física, incrementado factores de riesgos psicosociales como aislamiento y violencia intrafamiliar, pobreza y abuso de nuevas tecnologías, dando como resultado trastorno por estrés postraumáticos, duelo, ansiedad y depresión (Del castillo \& Velasco, 2020). Además, en México, se realizó una investigación para conocer la percepción de jóvenes universitarios respecto a la nueva modalidad de estudio, debido a pandemia de COVID-19; estos registraron sentimientos de malestar respecto a las clases a distancia y se evidenció un impacto en la salud mental de un 59\% de la población estudiantil (Frutos \& Tello, 2020). En la misma línea, un estudio realizado en Perú indicó que el 54\% de los estudiantes presentan ansiedad leve, el 35.8\% estrés moderado, el $22.4 \%$ bajo autocontrol y el $26.8 \%$ conductas agresivas (Casimiro et al., 2020). Acerca de las actitudes respecto a la COVID-19, Ruiz-Aquino (2020) encontró que, en Perú, el 91.40\% de los casos refirió actitudes pesimistas como: "tarde o temprano vamos a morir"; esto se relacionó con el estado de ánimo de los jóvenes participantes.

\section{Adultos mayores}

El adulto mayor ha sido el centro de atención durante la pandemia de COVID-19, ya que ha sido el grupo de edad con mayor impacto negativo. Uno de los principales factores de riesgo para enfermar de COVID-19 es la edad, debido a la acumulación de daños moleculares y celulares, enfermedades respiratorias crónicas, la desregulación del sistema inmunológico, entre otros aspectos; esto impacta dramáticamente la salud y, por lo tanto, este grupo etario es susceptible a contraer enfermedades y presentar síntomas graves (Espin et al., 2020); sin embargo, el riesgo puede darse por otros factores "como el daño emocional que les genera el confinamiento involuntario a partir de la prohibición de visitas familiares, que las priva del contacto personal y las desigualdades en los niveles de prestación de los servicios" (Cataldi, 2020, p.1). 
Un estudio realizado en España refirió que la mayoría de los 20453 fallecidos, al 19 de abril de 2020, era mayor a los 70 años. Asimismo, los autores encontraron que los principales motivos de la mortalidad fueron la elevada comorbilidad y la alta prevalencia de demencia, lo que favoreció las manifestaciones severas y el ingreso a unidades de cuidados intensivos (Tarazona-Santabalbina et al., 2020). En México, la COVID-19 ha representado un grave problema de salud en adultos mayores, que ha sido el grupo más vulnerable durante la pandemia. En los 15.4 millones de personas de 60 años o más que residían en el país, la tasa de mortalidad reportada ha sido de 51 defunciones por cada mil casos confirmados (Naranjo-Hernández et al., 2021; Vega et al., 2020).

La vacuna es una forma sencilla, inocua y eficaz para protegernos contra enfermedades dañinas y activar defensas; tras una vacunación, nuestro sistema inmunitario produce anticuerpos. Actualmente, existen diferentes vacunas contra la COVID-19 como las siguientes: Pfier/BioNTech, AstraZeneca/Oxford, Janssen, Moderna, Sinopharm y Sinovac; sin embargo, la efectividad de una vacuna depende de múltiples factores: el tipo de vacuna, el número de dosis, el tiempo transcurrido de la aplicación de ellas, la edad y las características de salud de las personas (Torres, 2021).

Como se ha visto en este capítulo, la enfermedad de COVDID-19 ha afectado a todas las etapas de desarrollo. La pandemia ha impacto en la salud mental de la población, reaccionando de manera emocional y conductual. El confinamiento, el distanciamiento social, las afectaciones económicas, el desempleo, entre otros aspectos, han provocado trastornos de ansiedad y depresión. En los trabajadores de la salud se han presentado riesgos elevados a su salud física como mental, registrando un mayor número de síntomas en las enfermeras, las mujeres y los profesionales de salud de primera línea, ya que tienen contacto directo con el paciente. En los menores de edad hay poca investigación, sin embargo, también se han presentado estudios que reflejan angustia emocional, aislamiento social y miedo a la muerte (Martinez-Taboas, 2020). 


\section{Referencias}

Apaza, C. M., Sanz, R. S. S., \& Arévalo, J. E. S. C. (2020). Factores psicosociales durante el confinamiento por el Covid-19-Perú. Revista Venezolana de Gerencia, 25(90), 402413.

Atamari-Anahui, N., Conto-Palomino, N. M., \& Pereira-Victorio, C. J. (2021). Actividades de inmunización en el contexto de la pandemia por la COVID-19 en Latinoamérica. Revista Peruana de Medicina Experimental y Salud Pública, 37, 773-775.

Casimiro, J. F., Benites, J. C., Sánchez, F. D. M., Flores, V. R., \& Palma, F. (2020). Percepción de la conducta por aislamiento social obligatorio en jóvenes universitarios por Covid-19. Revista Conrado, 16(77), 74-80. https://conrado.ucf.edu.cu/index.php/ conrado/article/view/1569

Cataldi, M. (2020). El aislamiento social en las personas mayores institucionalizadas en el marco de la Pandemia de coronavirus COVID-19. Margen, (97), 1-6.

Center for Systems Science and Engineering. (2021). Coronavirus resource center, COVID-19 Dashboard by the Center for Systems Science and Engineering (CSSE). https://coronavirus. jhu.edu/map.html

Ciotti, M., Ciccozzi, M., Terrinoni, A., Jiang, W.-C., Wang, C.-B., \& Bernardini, S. (2020). The COVID-19 pandemic. Critical Reviews in Clinical Laboratory Sciences, 1-24.

Clavellina, J. L. (2020). Posibles efectos del Coronavirus en la economía mundial. Notas estratégicas, (75). http://bibliodigitalibd.senado.gob.mx/handle/123456789/4805

Del Castillo, R. P., \& Velasco, M. P. (2020). Salud mental infanto-juvenil y pandemia de Covid-19 en España: cuestiones y retos. Revista de psiquiatría infanto-juvenil, 37(2), 30-44.

Deville, J. G., Song, E., \& Ouellette, C. P. (2021). COVID-19: Clinical manifestations and diagnosis in children. UpToDate.

Espin, J., Cardona, A., Miret, L., \& González, M. (2020). La COVID-19 y su impacto en la salud del adulto mayor. Archivos del Hospital Universitario "General Calixto García", 8(3). http://www.revcalixto.sld.cu/index.php/ahcg/article/view/568/563

Fernández, J. H. (2021). La variante delta del COVID-19: ¿qué podemos esperar? Revista Mutis, $11(2)$.

Fisman, D., \& Tuite, A. (2021). Progressive Increase in Virulence of Novel SARS-CoV-2 Variants in Ontario, Canada.MedRxiv. https://doi.org/10.1101/2021.07.05.21260050 
Fondo de las Naciones Unidas para la Infancia. (2020a). Cómo cuidar tu salud mental en tiempos de pandemia. https://www.unicef.org/ecuador/historias/c\%C3\%B3mocuidar-tu-salud-mental-en-tiempos-de-pandemia

Fondo de las Naciones Unidas para la Infancia. (2020b). El impacto del COVID-19 en la salud mental de adolescentes y jóvenes. https://www.unicef.org/lac/el-impacto-delcovid-19-en-la-salud-mental-de-adolescentes-y-j\%C3\%B3venes

Frutos, M., \& Tello, R. (2020). El impacto del COVID-19 en la salud mental de los jóvenes universitarios. Revista de Administración Publica, 55(2), 129-146. http://www. repositorio.unacar.mx/jspui/handle/1030620191/531

Gómez, A. (2021). Impacto de la pandemia de COVID-19 en los síntomas de salud mental y actuaciones de fisioterapia. Fisioterapia, 43(1), 1-4. https://doi.org/10.1016/j. ft.2020.11.001

Gould, M. S. F., Diaz, G. C., \& Vargas, M. A. R. (2021). Impacto sobre la salud mental durante la pandemia COVID 19 en Paraguay. Revista Virtual de la Sociedad Paraguaya de Medicina Interna, 8(1), 61-68. https://doi.org/10.18004/rvspmi/2312-3893/2021.08.01.61 Hernández, H. (2021). COVID-19 en México: un perfil sociodemográfico. Notas de Población. Huamán-Saavedra, J. J. (2020). La pandemia del COVID-19. Revista Médica de Trujillo, 15(2), 53-54. http://dx.doi.org/10.17268/rmt.2020.v15i02.01

Huarcaya-Victoria, J. (2020). Consideraciones sobre la salud mental en la pandemia de COVID-19. Revista Peruana de Medicina Experimental y Salud Publica, 37, 327-334.

Llover, M. N., \& Jiménez, M. C. (2021). Estado actual de los tratamientos para la COVID-19. FMC: Formación Medica Continuada en Atención Primaria, 28(1), 40-56. https://doi. org/10.1016/j.fmc.2020.10.005

López, P. L., Medina, E. L., \& Reina, I. B. (2020). Diferencias entre niños y adultos por el nuevo coronavirus 2019, SARS-CoV-2/COVID-19. Revista Latinoamericana de Infectología Pediátrica, 33(4), 165-173.

Mallapaty, S. (2021). COVID vaccines slash viral spread - but Delta is an unknown. Nature, 596(7870), 17-18. https://doi.org/10.1038/d41586-021-02054-z

Marín-Sánchez, A. (2020). Características clínicas básicas en los primeros 100 casos fatales de COVID-19 en Colombia. Revista Panamericana de Salud Publica, 44, e87. https:// doi.org/10.26633/RPSP.2020.87 
Martínez-Taboas, A. (2020). Pandemias, COVID-19 y Salud Mental: ¿Qué Sabemos Actualmente? Revista Caribeña de Psicología, 4(2), 143-152. https://doi.org/10.37226/ rcp.v4i2.4907

Naranjo-Hernández, Y., Mayor-Walton, S., Rivera-García, O. D. L., \& González-Bernal, R. (2021). Estados emocionales de adultos mayores en aislamiento social durante la COVID-19. Revista Información Científica, 100(2).

Organización Mundial de la Salud. (2020). Nuevo Coronavirus 2019. https://www.who.int/ es/emergencies/diseases/novel-coronavirus-2019

Parker, S. (2020). Uso del Tiempo de los Adolescentes durante la Pandemia en México: Una Mirada Inicial. Foco Económico.

Quiroz, C. G., Pareja, A., Valencia, E., Enríquez, Y. P., De Leon, J., \& Aguilar, P. (2020). Un nuevo coronavirus, una nueva enfermedad: COVID-19. Horizonte Médico (Lima), 20(2), e1208. https://doi.org/10.24265/horizmed.2020.v20n2.11

Ramos, C. (2020). Covid-19: la nueva enfermedad causada por un coronavirus. Salud Pública De México, 62(2), 225-227. https://doi.org/10.21149/11276

Rosero, A., Carvajal, J., \& Fabio, E. (2021). Percepción de riesgo frente al Covid-19 en adolescentes escolarizados colombianos. Revista Boletín Redipe, 10(3), 376-392.

Ruiz-Aquino, M., Diaz-Lazo, A., \& Ortiz-Aguí, M. (2020). Creencias, conocimientos y actitudes frente a la COVID-19 de pobladores adultos peruanos en cuarentena social. Revista Cubana de Enfermería, 36, e4251. http://www.revenfermeria.sld.cu/ index.php/enf/article/view/4251/672

Salcedo-Matienzo, J., Zavala-Flores, E., SalazarGavino, S., Eunofre-Hipolo, B., \& BerrocalKasay, A. (2020). Adultos jóvenes hospitalizados por COVID-19. Acta Médica Peruana, 37(4), 568-571.

Sánchez-Ríos, C. P., Jiménez-Cabrera, O. G., Barreto-Rodríguez, O., \& Téllez-Navarrete, N. A. (2021). Enfermedad COVID-19 en adultos jóvenes mexicanos hospitalizados. NCT Neumología y Cirugía de Tórax, 80(2), 105-110.

Tarazona-Santabalbina, F. J., Martínez-Velilla, N., Vidán, M. T., \& García-Navarro, J. A. (2020). COVID-19, adulto mayor y edadismo: errores que nunca han de volver a ocurrir. Revista Española de Geriatría y Gerontología, 55(4), 191-192. https://doi. org/10.1016/j.regg.2020.04.001 
Torres, C. (2021). Covid-19. Variante Delta y efectividad de vacunas. Temas estratégicos, (94). http://bibliodigitalibd.senado.gob.mx/handle/123456789/5404

Vásquez, C., Ruz, F., \& Martínez, M. V. (2020). Recursos virtuales para la enseñanza de la estadística y la probabilidad: un aporte para la priorización curricular chilena frente a la pandemia de la COVID-19. TANGRAM-Revista de Educação Matemática, 3(2), 159183.

Vega, J. A., Ruvalcaba, J. C., Hernández, I., Acuña, M. D. R., \& López, L. (2020). La salud de las personas adultas mayores durante la pandemia de COVID-19. Journal of Negative and No Positive Results, 5(7), 726-739.

Wong-Chew, R. M., Noyola, D. E., \& Villa, A. R. (2021). Características Clínicas y Factores De Riesgo De Mortalidad En Menores De 18 Años Con Covid-19 En México Y Ciudad De México. Anales de Pediatría. https://doi.org/10.1016/j.anpedi.2021.07.014 


\section{Capítulo 2}

\section{Funcionamiento familiar: evaluación de obstructores en tiempos de COVID-19}

Jorge Arturo Martínez Gómez, Yolima Bolívar Suárez

y María Nancy Mendoza Bautista

Las familias tienen una función importante en la estabilidad de los miembros que la conforman. Las familias que tienen una comunicación altamente satisfactoria son para sus miembros un factor potenciador; por otra parte, las familias poco flexibles y con una comunicación problemática, se convierten en un factor obstructor, lo cual afecta la adaptabilidad y funcionamiento de sus miembros, y genera estados emocionales alterados y de riesgo para sus integrantes. Actualmente, las condiciones de salud pública debido a la pandemia llevaron a que las familias utilizaran sus recursos para enfrentar el aislamiento social y los problemas económicos, laborales, académicos y sanitarios que se derivaron de las medidas tomadas por los gobiernos para frenar la propagación de la COVID-19; esto puso a prueba la homeostasis de los sistemas familiares. Por lo tanto, este capítulo busca analizar el impacto de la pandemia de COVID-19 en el funcionamiento familiar.

\section{Sallud familiar}

La definición de familia se ha abordado desde múltiples perspectivas, lo cual ha nutrido su conceptualización; actualmente, se han generado cambios en las dinámicas sociales, llevando a nuevas estructuras de familia. En general, se considera que la familia es la institución fundamental de la sociedad y, por lo tanto, pieza clave para entender las dinámicas sociales, pues es la encargada de formar a las nuevas generaciones, transmitir normas, valores y tradiciones culturales (Gustavino, 1987). 
Desde la antropología, la familia se analiza a partir del parentesco (Oliva \& Villa, 2014); para la sociología, es la familia el sujeto social básico para procesos de socialización, protección y mediación con otros grupos y niveles sociales (Donati, 2003); en el caso de la psicología, la familia se considera un sistema que se caracteriza por las relaciones y vínculos afectivos que son base para su funcionamiento y para el desarrollo de sus integrantes (Acevedo \& Vidal, 2019). La economía plantea que la familia tiene dentro de sus funciones satisfacer necesidades básicas de subsistencia y protección (alimentación, vivienda, servicios públicos, educación, salud, entre otros), así como establecer una economía del hogar que coadyuve a este propósito, para ello es necesario que las familias puedan acceder a opciones laborales en condiciones dignas (Sandoval \& Hernández, 2018). Para la enfermería, la familia es sujeto de cuidado, caracterizado por una estructura organizada con subsistemas interpersonales ligadas por lazos emocionales y responsabilidades compartidas. La familia como sistema interactúa con su medio ambiente y demás sistemas sociales; esto puede llevarla a enfrentar amenazas y afectar su homeostasis (Friedemann, 1995).

El funcionamiento familiar desde la perspectiva sistemática plantea que la familia posee atributos que caracterizan la forma de funcionar o sus dinámicas para operar (McCubbin \& Patterson, 1983), se espera que una familia sea funcional en la medida que pueda mantener la homeostasis reflejada en la vinculación emocional entre sus miembros, la apertura y capacidad de cambio en su estructura y roles de acuerdo con los retos o demandas externas, lo que les permitirá ajuste y adaptación.

La salud familiar es la congruencia manifestada por los miembros y por la familia, como resultado del proceso equilibrado de interacción del sistema familiar con su ambiente. Esto se puede evidenciar en la medida en que la familia tiene estrategias de afrontamiento, percibe baja ansiedad o estrés y alta satisfacción de los miembros con el sistema familiar, retroalimentación positiva de ambiente u otros sistemas sociales hacia los miembros de la familia, o la familia como unidad que aporta a la comunidad. Esto se da en un contexto activo, dinámico, cambiante y complejo que lleva a buscar nuevas formas de retomar el equilibrio o congruencia del sistema, siempre en relación con el ambiente (Friedemann, 1995).

Como resultado del proceso de desarrollo de los integrantes de la familia, del funcionamiento familiar, del ciclo vital familiar y la interacción del sistema familiar 
con otros sistemas y determinantes sociales, se generan las condiciones de la salud familiar, así como los recursos para afrontar los cambios y crisis a lo largo de su historia (García et al., 2016). En el momento que la familia tenga que enfrentar una crisis como, por ejemplo, una enfermedad que afecte a uno o a todos sus integrantes, tal es el caso de la infección por SARS-Cov2, todos los recursos y sistemas de apoyo se verán involucrados o afectados. Ante la situación de la pandemia de COVID-19, fue necesario declarar estado de cuarentena. En algunos países como Colombia, su duración fue de varios meses de encierro, lo cual generó cambios positivos y negativos en las dinámicas familiares.

$\mathrm{Al}$ analizar la tendencia de la investigación sobre la familia en tiempos de contingencia sanitaria por COVID-19, se encontró que la situación de pandemia y cuarentena ha motivado la realización de investigaciones que han ayudado a comprender los diversos procesos y cambios que se han generado en la familia. Al hacer una revisión de bases de datos, como Pub Med, con la ecuación de búsqueda (Family[MeSH Major Topic]) AND (COVID 19[MeSH Major Topic]), de artículos de revistas en el último año, arrojó un total de 59 documentos que abordan el estudio de los siguientes temas y su implicación en diversas etapas del ciclo vital familiar: (a) Ansiedad, depresión, estrés, angustia, demencia; (b) Educación y comportamientos en salud para afrontar la pandemia; (c) Enfermedad crónica; (d) Infección por COVID-19 en contexto domiciliario; (e) Lactancia materna; y (f) Comunicación con familiares aislados por COVID-19. Son escasas las investigaciones que estudien la afectación de las dinámicas familiares en tiempo de pandemia, o que busquen hacer intervención o prevención de este tipo de problemáticas para la promoción de familias saludables.

\section{Implicaciones familiares ante la enfermedad por COVID-19}

Ante situaciones de crisis, las familias tienen la capacidad de adaptarse o no a las necesidades que surgen, así como de mantenerse o no unidas para afrontarla. En la pandemia de COVID-19, las familias se han enfrentado a múltiples y complejos problemas que se configuraron como obstructores de su funcionamiento, algunos de ello son del orden: (a) Económico: cierre de empresas, despidos masivos, pocas opciones de empleo, altos índices de trabajo informal que no podían salir a la calle 
a buscar el sustento diario, alto costo o escasez de elementos de protección personal como tapabocas, reducción en la capacidad adquisitiva y de cumplimiento en el pago de deudas; (b) Educativo: cierre temporal de universidades, colegios y jardines infantiles; cambio de educación presencial a virtual a nivel universitario y educación básica, barreras de acceso a internet o equipos de cómputo, dificultad por parte de padres o cuidadores para supervisar o acompañar el proceso de aprendizaje remoto; (c) Salud: barreras para el acceso a servicios de salud (consultas, exámenes diagnósticos, procedimientos, medicamentos entre otros), problemas de salud mental, infección de algún miembro de la familia por SARS-Cov2, muerte de miembros de la familia por SARS-Cov2, integrantes de la familia con enfermedad crónica y limitaciones en el acceso a los programas y servicios, alteraciones de sueño, violencia intrafamiliar, entre otros.

A continuación, se analizan algunos obstructores del funcionamiento familiar como la crisis económica, la violencia de pareja e intrafamiliar, la enfermedad crónica y los procesos de duelo y muerte.

\section{La crisis económica como un obstructor de la funcionalidad familiar}

Antes de la pandemia, los indicadores de crecimiento económico a nivel latinoamericano no eran los mejores (Vasquez \& Reyes, 2019), lo cual hizo que la capacidad para enfrentarla fuera reducida y limitada. De manera particular, Colombia en el año 2019 mostró un crecimiento económico del 3.3\%, mayor al alcanzado a nivel latinoamericano con el 0.1\% (Bárcena, 2020). Sin embargo, en los primeros meses del 2020, debido a la disminución en el precio del petróleo y a la condición de pandemia por SARS-Cov2, las proyecciones positivas cambiaron. El panorama se complejizó en la medida que una de las principales fuentes de ingresos (petróleo) se redujo, las medidas de confinamiento conllevaron a detrimento económico y aumento considerable de los gastos para asumir la atención de la población afectada por la infección. Al cierre del año 2020 se presentó una recesión económica y hubo una contracción del Producto Interno Bruto (PIB) en un 6.8\%, de acuerdo con las cifras del Departamento Administrativo Nacional de Estadísticas (Salazar, 2021).

Al estimar el impacto económico de cada mes de confinamiento, de acuerdo con Mejía (2020), estuvo alrededor del rango de 48 a 65 billones de pesos (4.5\% a 
6.1\% del PIB), esto llevó a que muchas empresas redujeran puestos de trabajo o incluso algunas quebraran. Asimismo, los trabajadores informales también tuvieron que dejar de laborar y mantenerse durante meses en confinamiento, condición que ahondó las inequidades en este grupo vulnerable (Ricciulli-Marín et al., 2020). La tasa de desempleo nacional pasó del 10.7\% en julio de 2019 al 20.2\% en julio del 2020, fue más alta en las mujeres (26.2\%) que en los hombres (16.2\%) y la tasa de desempleo en los jóvenes se ubicó en 29.7\% (Hoyos, 2020).

Estos cambios también han impactado la economía familiar, reflejándose en el incremento de los niveles de pobreza y, por ende, los indicadores de calidad de vida. Las familias que durante la pandemia han tenido uno o varios miembros infectados y cuyas condiciones socioeconómicas no son favorables han reportado mayores tasas de ingreso a unidades de cuidado intensivo (UCI) y mortalidad. El Grupo de Investigación en Macroeconomía de la Facultad de Economía de la Universidad de los Andes (2020) estimó para Bogotá, que una persona de nivel socioeconómico bajo (estrato 1) puede ser seis veces más probable que ingrese a una UCI y diez veces más probable que resulte hospitalizado o fallezca por COVID-19, en contraste con una persona de nivel socioeconómico alto (estrato 6). El DANE (2021) reportó que 87\% de las muertes por COVID-19 en Colombia fueron en estratos 1, 2 y 3 (nivel bajo y medio) y personas con nivel de educación de básica primaria, de los cuales el 21.5\% correspondieron a hombres y $15.1 \%$ a mujeres.

En este contexto, las familias pudieron o no tener la capacidad de adaptarse o ser flexibles antes las amenazas y riesgos derivados de la COVID-19, como perder la vida, el trabajo, la vivienda, la educación; o tener miedo de contagiar a sus familiares en la medida que se tenga que salir a trabajar o buscar empleo (Caccia \& Perez, 2021); además, propició conflictos entre sus miembros por la escasez de recursos económicos para suplir las necesidades básicas de subsistencia o por la organización de nuevas tareas que se derivaron por el confinamiento. Diversos estudios han evidenciado que, a partir de la pandemia, las personas han manifestado síntomas como ansiedad, depresión, estrés, pérdida de la calidad de sueño, así como aumento en el consumo de sustancias psicoactivas (Martínez et al., 2020; McPhee et al., 2020) que, junto con los cambios en la economía familiar, pueden llevar a procesos de disfuncionalidad familiar. 


\section{Violencia de pareja e intrafamiliar durante la pandemia de COVID-19}

La pandemia de COVID-19 llevó a que los gobiernos de los países tomaran medidas estrictas preventivas de aislamiento social, con el fin de frenar la propagación de la enfermedad; sin embargo, estas medidas tuvieron un efecto en las dinámicas familiares y en la forma como los miembros se relacionaban, debido a que estar confinados en espacios reducidos afecta tanto la salud física como la mental, generando estados emocionales y afectivos de alto riesgo con síntomas de trastornos mentales y comportamientos desadaptativos, presentándose en algunos casos violencia de pareja o intrafamiliar (Ahmed et al., 2020; Huang \& Zhao, 2020; Lei et al., 2020). Las investigaciones iniciales del impacto del aislamiento en la salud de las personas, durante la actual pandemia, demuestran que la cuarentena por la COVID-19 ocasiona un grave impacto emocional en la población adulta, en la que predominan síntomas de ansiedad, depresión y estrés de gravedad moderada a severa (Luo, 2020; Odriozola-González et al., 2020; Ozamiz-Etxebarria et al., 2020).

Estas medidas estrictas de distanciamiento social y cuarentena tuvieron como resultado que las personas y organizaciones incorporaran nuevas formas para el desarrollo de las actividades laborales, educativas y familiares. Como consecuencia, muchas familias vieron afectada su estabilidad económica, debido a que en muchos hogares el jefe de familia perdió su puesto de trabajo; esto generó la búsqueda de alternativas para la generación de recursos económicos, acompañado de malestar emocional, caracterizado por episodios de ansiedad, síntomas depresivos, estrés y desesperanza hacia el futuro. Por lo tanto, las familias tuvieron que reorganizar su manera de funcionar y articular actividades laborales, domésticas y de cuidado de hijos menores. Asimismo, el cierre preventivo de los centros educativos afectó la organización familiar, en mayor medida a las mujeres (Alon et al., 2019; Ko et al., 2006; Tavares et al., 2020), lo cual podría estar relacionado con mayores niveles de estrés en la crianza (Cluver et al., 2020).

Los factores anteriores están relacionados con violencia de pareja e intrafamiliar durante el tiempo de cuarentena. Al respecto, Ko et al. (2006) describieron que, en el 2003, durante la epidemia del SARS, las personas que estuvieron en aislamiento mostraron mayores síntomas depresivos, debido al impacto en la recesión económica, las malas condiciones de salud y el inadecuado apoyo social. 
Las condiciones estrictas de confinamiento llevaron a que las familias, que tenían algún miembro con historial de trastornos mentales o de violencia intrafamiliar, convivieran con él mayor tiempo en el hogar, lo que aumentó el riesgo de presentarse episodios de violencia en la familia (Mazza et al., 2020). Además, variables contextuales que pueden estar relacionadas con la aparición de violencia doméstica como, por ejemplo, la sobrecarga laboral, los nuevos roles en el papel que desempeñaban los padres en la formación académicas de sus hijos, la afectación y la incertidumbre con respecto a la situación económica y laboral, la pérdida de recursos económicos y del empleo, podrían afectar la salud mental de los integrantes de la familia y, en muchos casos, favorecer la ejecución de conductas de violencia de pareja (Gelder et al., 2020).

Zero y Geary (2020) describieron en su investigación que las conductas que emplean los victimarios van desde controlar los recursos económicos y la alimentación hasta el aislamiento total, sin poder contactarse con ningún familiar o red de apoyo, bajo amenazas de retaliación contra la víctima u otros miembros del hogar.

En Colombia, durante la cuarentena obligatoria, se presentó un incremento en las denuncias por violencia intrafamiliar. El Observatorio Colombiano de las $\mathrm{Mu}$ jeres (2020) informó que el número de denuncias de violencia intrafamiliar tuvo un crecimiento del 142\% durante el aislamiento obligatorio (entre el 25 de marzo y el 11 de abril del 2020), esta cifra comparada con el mismo periodo del año anterior. Además, en la línea telefónicas de ayuda de Bogotá DC, durante el periodo de cuarentena se habían registrado un total de 9000 llamadas y mensajes de texto pidiendo auxilio, esta tendencia se repitió en otras ciudades del país; sin embargo, las cifras oficiales del Instituto Nacional de Medicina Legal y Ciencias Forenses (2020) indicaron una disminución en las denuncias de los casos de violencia de pareja y los demás tipos de violencia intrafamiliar en Colombia, en el periodo de enero a abril, con respecto al mismo periodo del año anterior; esto se debió, probablemente porque las entidades de recibir las denuncias se encontraban en cierres preventivos, lo cual llevó a que el gobierno tomara medidas y diera la reapertura de las Comisarías de Familia durante la cuarentena. No obstante, la Organización Panamericana de la Salud (OPS, 2020) informó que, desde el brote de la COVID-19, países como China, Reino Unido y Estados Unidos señalaron un incremento en los casos de violencia doméstica. 
Es importante que se implementen estrategias para prevenir y disminuir el efecto que ha tenido la cuarentena en las dinámicas familiares y en la aparición de la violencia intrafamiliar. Se recomienda hacer intervención universal, debido a que las condiciones de aislamiento pueden provocar cambios en las dinámicas familiares y, en algunos casos, la aparición de conductas de violencia intrafamiliar. Además, se debe entrenar al personal de salud en la identificación de las posibles víctimas y en el uso de instrumentos de tamizaje para examinar los diferentes tipos de violencia de pareja, de esta forma, activar las rutas de atención correspondientes (Gelder et al., 2020; Mazza et al., 2020).

\section{Enfermedad crónica como factor estresor en la familia}

La Organización Panamericana de la Salud (OPS, 2021) reportó que las enfermedades crónicas no transmisibles (ECNT) representan el 71\% de la mortalidad anual, es decir, que cobran la vida de 41 millones de personas a nivel mundial y en América 5.5 millones cada año. Una de las mayores preocupaciones es que, estas muertes, 15 millones son adultos jóvenes y maduros (entre 30 y 69 años), se dan en países en vía de desarrollo y representan para la sociedad la pérdida de muchos años productivos.

Las personas y familias que viven situaciones de ECNT (i. e., enfermedades cardiovasculares, pulmonares, diabetes, insuficiencia renal, cáncer, obesidad, entre otras), se enfrentan a cambios importantes en su rutina diaria, pues al interior del grupo familiar se debe suplir diversas necesidades como: cuidados básicos, administración de medicamentos, suministro o acompañamiento para adoptar cambios en la alimentación, actividad física, sensación o reducción en el consumo de alcohol o tabaco, procesos administrativos en el sistema de salud para realizar autorizaciones para exámenes, consultas y demás controles que requiere la persona con ECNT, además del acompañamiento a cada uno de ellos. Este contexto exige de la persona y su familia alta carga por la cantidad y complejidad de muchas de estas actividades, lo cual resulta en ocasiones en el deterioro de la salud del cuidador familiar y aumento en los gastos económicos, empobreciendo a las familias o generando conflictos en sus miembros (Salazar et al., 2020).

Las familias que tienen algún integrante con enfermedad crónica durante la pandemia de COVID-19, posiblemente, no pudieron tener la capacidad de adaptarse 
y ser flexibles ante los cambios del medio ambiente, más aún cuando las personas con ECNT está considerada uno de los grupos poblacionales con mayor riesgo de complicaciones. Se estima que la existencia de comorbilidades aumenta 2.4 veces la probabilidad de morir por COVID-19, en comparación con quienes no tienen condiciones preexistentes (Vences et al., 2020), por lo tanto, fue uno de los grupos con mayores restricciones en el proceso de confinamiento. Por un lado, se buscaba su protección al mantenerlos aislados, no obstante, su proceso de seguimiento y controles por parte del sistema de salud se vio interrumpido; por otro lado, cuando se fue reestableciendo la atención presencial, muchas personas y familias, por el temor al contagio, no acudieron a los centros de salud o consultorios; además, las alternativas de telesalud en muchos casos no son accesibles a la mayoría de la población, sobre todo para quienes viven en sectores rurales y rurales dispersos, por lo tanto, su impacto fue reducido. Este panorama ha generado descompensación y complicaciones prematuras que habrían podido ser detectadas y prevenidas a tiempo (Yang et al., 2020).

\section{Muerte y duelo en tiempos de COVID-19}

Al ser la muerte un proceso inherente para todo ser vivo, los humanos a través del tiempo le hemos otorgado distintos significados a este periodo trascendental y de gran impacto. Una de las expresiones más empleadas en la actualidad es el término duelo, que al derivarse del latín dolus es entendido como 'dolor', siendo esta una reacción sana acompañada de tristeza o angustia por la pérdida de alguien apreciado, una mascota, una capacidad psicológica o física, o de un objeto valioso (D’Aspremont \& Monbourquette, 2012).

El duelo en la actualidad es considerado más como un proceso que como un estado; se caracteriza por ser un constructo subjetivo, multidimensional, complejo y diverso, en el que influye características personales, sociales y comunitarias (García, 2020).

La duración de este proceso dependerá de las capacidades adaptativas, al igual que del entorno en el que se encuentre la persona doliente; se suelen atravesar diferentes etapas durante la superación de esta fase, sin embargo, no existe un consenso académico sobre la denominación y el número exacto de etapas a seguir en su 
transcurso, encontrando así la existencia de tres a cinco niveles (Ortego \& Alconero, 2001).

La categorización más conocida es el modelo DABDA, por sus siglas en inglés, o NINDA en español, brindado por Elisabeth Kübler (Kübler-Ross \& Kessler, 2016), siendo estas la negación, la ira, la negociación, la depresión y la aceptación; esta autora resalta que el trascurrir de estas etapas no suele ser lineal, ya que se pueden presentar retrocesos o simplemente existen casos donde la persona no atraviesa todas las etapas propuestas, haciendo de esta clasificación algo no universal.

Por su parte, el luto se relaciona con el duelo, pero se diferencia de este debido a que, el luto es entendido como la respuesta social ante la pérdida, haciendo referencia con esto a los rituales o comportamientos sociales externos que dictaminan las pautas a seguirse (Castro, 2007).

La muerte de alguien cercano es en sí mismo un proceso de transición, es decir, cambiar del modo de ser o estar a otro estado distinto, pero las circunstancias que rodean este cambio pueden facilitar o impedir dicha transición.

Los procesos de pérdida son entendidos como una crisis no transitoria o paranormativa en relación con el ciclo vital cronológico y, a su vez, como una fuente generadora de estrés, ya que se presenta un estado de cambio tanto a nivel individual como a nivel familiar, y del que no todos los miembros entienden y viven, ya sea el proceso de duelo o el luto, de la misma manera. González (2000) planteó que este tipo de crisis puede desencadenar eventos de desmembramiento, es decir, se caracteriza por la separación de algún miembro familiar, generando así dificultades. La muerte, pese a clasificarse como una vivencia paranormativa, también se puede entender como un suceso esperado en los casos de hospitalizaciones por enfermedades graves.

Si bien, los altos índices de mortalidad por epidemias no es algo nuevo para la humanidad, la pandemia actual se constituyó como una amenaza de muerte directa y cercana; intrínsecamente, la muerte posee connotaciones negativas, generando en el ser humano una amplia variedad de emociones con diferentes intensidades.

Bajo condiciones normales, al aumentar nuestro grado de consciencia frente a nuestra propia mortalidad suelen aparecer síntomas de depresión, miedo y ansiedad, sin embargo, con lo que se vive actualmente a causa del virus de COVID-19, este 
ambiente se ha convertido en un potenciador de dichos sentimientos. Tomás-Sábado (2020) describió tres determinantes principales de la ansiedad ante la muerte: (a)las experiencias previas con la muerte, (b) el nivel de salud psicológica y (c) el significado atribuido a la vida y a la finalización de esta, los cuales varían acorde a acontecimientos vitales y que por la pandemia han estado aumentando el grado de ansiedad ante la muerte.

En la actualidad, y dada la situación vivida a causa de la pandemia de COVID-19, los familiares de quien sufre o ha sufrido un contagio por este virus se ven inmersos en un choque cultural, al tener que optar por el bien público y dejar de lado sus sentimientos y valores propios. Esta disyuntiva es evidente y exacerbada, dado que los actos sociales propios de las pérdidas han sido eliminados, es decir, el doliente no cuenta con el mismo nivel de apoyo social y no puede desarrollar sus ritos fúnebres como de costumbre, asimismo, se presenta una pérdida sobre la elección del rito fúnebre y la imposición de la cremación como única opción para quienes fallecieron por COVID-19.

Con lo anterior, se podría dar paso a casos de disonancia cognitiva significativos, ya que, trasladando al contexto actual los postulados de esta teoría brindada por León Festinger en 1957 (Figueroa, 2016), las actitudes y deseos de los familiares de algún caso de deceso por COVID pueden ser contrarias a las disposiciones finales para el proceso de inhumación que se exigen a nivel sanitario para este tipo de casos, perturbando de este modo el proceso de toma de decisión familiar y, por lo tanto, obstaculizando el adecuado proceso de duelo y ajuste del funcionamiento familiar.

\section{La situación de la familia de Alberto y Laura}

A continuación, se describe la situación de la familia de Alberto y Laura (caso hipotético) a través de la perspectiva teórica de Olson.

\section{Base conceptual del análisis de caso}

El modelo circumplejo agrupa los aspectos centrales y más evaluados del funcionamiento familiar, este tiene la capacidad de brindar un diagnóstico relacional basado en la valoración de la cohesión y la adaptabilidad, permitiendo su aplicabilidad con fines investigativos, prácticos o teóricos. 
La cohesión es entendida como el grado de unión entre los miembros del núcleo familiar; dentro de esta dimensión se evalúan aspectos como implicación familiar, fronteras internas y externas, lazos familiares y coaliciones padres-hijos, encontrándose así cuatro posibles niveles de clasificación, siendo estos: desvinculada (muy baja), separada (baja moderada), conectada (moderada alta) y enredada (muy alta) (Sigüenza et al., 2017).

La adaptabilidad hace referencia a la capacidad del sistema para adaptarse a las diferentes situaciones del ciclo vital, centrándose así en aspectos como cambio en el liderazgo, la disciplina, la negociación, los roles y las reglas del sistema, generando cuatro posibles niveles de clasificación, siendo estos: rígida (muy baja), estructurada (baja moderada), flexible (moderada alta) y caótica (muy alta) (Sigüenza et al., 2017).

Desde esta perspectiva, los niveles extremos de ambas dimensiones, es decir, desvinculada y enredada para cohesión, y rígida y caótica para adaptabilidad, son entendidos como desequilibrados o problemáticos; en contraposición a niveles de cohesión conectada o separada, y adaptabilidad estructurada o flexible, que son considerados como más equilibrados y funcionales (Olson, 2000).

\section{Caso hipotético}

Alberto es un hombre de 50 años que vive con su esposa y sus dos hijos, en un barrio perimetral de una ciudad capital de Colombia. Alberto trabajaba como vendedor ambulante, mientras que su esposa Laura trabajaba en servicios generales de una casa de familia, con esto cubrían las necesidades básicas de sus hijos menores de edad que se encontraban cursando primaria y bachillerato.

Esta familia solía compartir en el parque de su barrio los fines de semana, siendo este el principal tiempo en familia; entre semana, después de clases, los niños ayudaban a Alberto a recoger la mercancía del puesto, cenaban juntos y procuraban distribuirse las labores del hogar. Familia conectada-estructurada: Alta cohesión, interdependencia familiar, presencia del "nosotros" / Moderada adaptabilidad, liderazgo a veces compartido, roles estables, disciplina algo democrática (Punto A, ver Figura 1). 
Con la llegada de la pandemia de COVID-19 y las respectivas restricciones, los dos adultos quedaron sin trabajo; para las clases virtuales los hermanos debían compartir un teléfono celular, pero no era suficiente. Pese a que recibían un subsidio por parte del gobierno, no les alcanzaba para cubrir los gastos que tenían. Llevaban varios meses confinados y la convivencia se había tornado difícil, los niños se la pasaban discutiendo constantemente entre ellos, mientras que él veía cómo su esposa se ponía cada vez más triste y desanimada, lloraba mucho y ya casi no dormía, sin contar con que estaba dejando de comer. Familia conectada-rígida: Moderada cohesión, interdependencia familiar, presencia del "yo-nosotros" / Baja adaptabilidad, disciplina estricta y liderazgo autoritario (Punto B, ver Figura 1).

Alberto desesperado optó por volver a poner su puesto en la calle, durante las dos primeras semanas todo pareció estar bien, pero de un momento a otro, su esposa empezó a presentar fiebre, dolor de cabeza y tos, mientras que el menor de sus hijos presentaba náuseas y había perdido el sentido del olfato. Tras los exámenes, ella y su hijo resultaron positivos a COVID-19, al igual que él, con excepción de que él era asintomático. El hijo mayor tuvo que prestar más atención al cuidado de los familiares enfermos. Familia enredada-flexible: Alta unión familiar con presencia de dependencia entre los miembros con descuido del yo o la individualidad / Moderada adaptabilidad entendida en cambio de roles, liderazgo compartido, adaptabilidad moderada (Punto C, ver Figura 1).

Al ser diabética, su esposa presentó complicaciones y tuvo que ser intubada, pero desafortunadamente a los pocos días falleció. Alberto al sentirse culpable por lo sucedido con su esposa recurrió al alcohol como medio de escape, su hijo mayor se retiró del colegio y el menor perdió el año académico. Familia desvinculada-caótica: Baja cohesión, separación emocional, poca participación colectiva, independencia individual, poca cercanía / Alta adaptabilidad traducida en falta de liderazgo, decisiones poco estratégicas, no hay claridad de roles (Punto D, ver Figura 1).

El caso anterior nos permite identificar cómo las familias estables y funcionales, donde los miembros se percibían unidos, cambian ante la aparición de obstructores en tiempo de COVID-19. En muchos casos, los obstructores generaron tensión en el sistema familiar, con consecuencias en la estructura, cohesión y flexibilidad, viéndose afectados los facilitadores de comunicación de sus miembros, llevando a la 
familia de una condición estructurada a una situación de caos y desconexión (Figura 1). Por lo tanto, es importante que las organizaciones y gobiernos protejan a la familia con un enfoque preventivo, mediante el diseño de programas que incorporen esquemas para la adaptación a los nuevos cambios sociales, económicas, laborales, educativos y en salud, con incentivos económicos que le permitan afrontar las amenazas y retos de la pandemia.

\section{Figura 1}

Modelo de funcionamiento familiar del caso de estudio

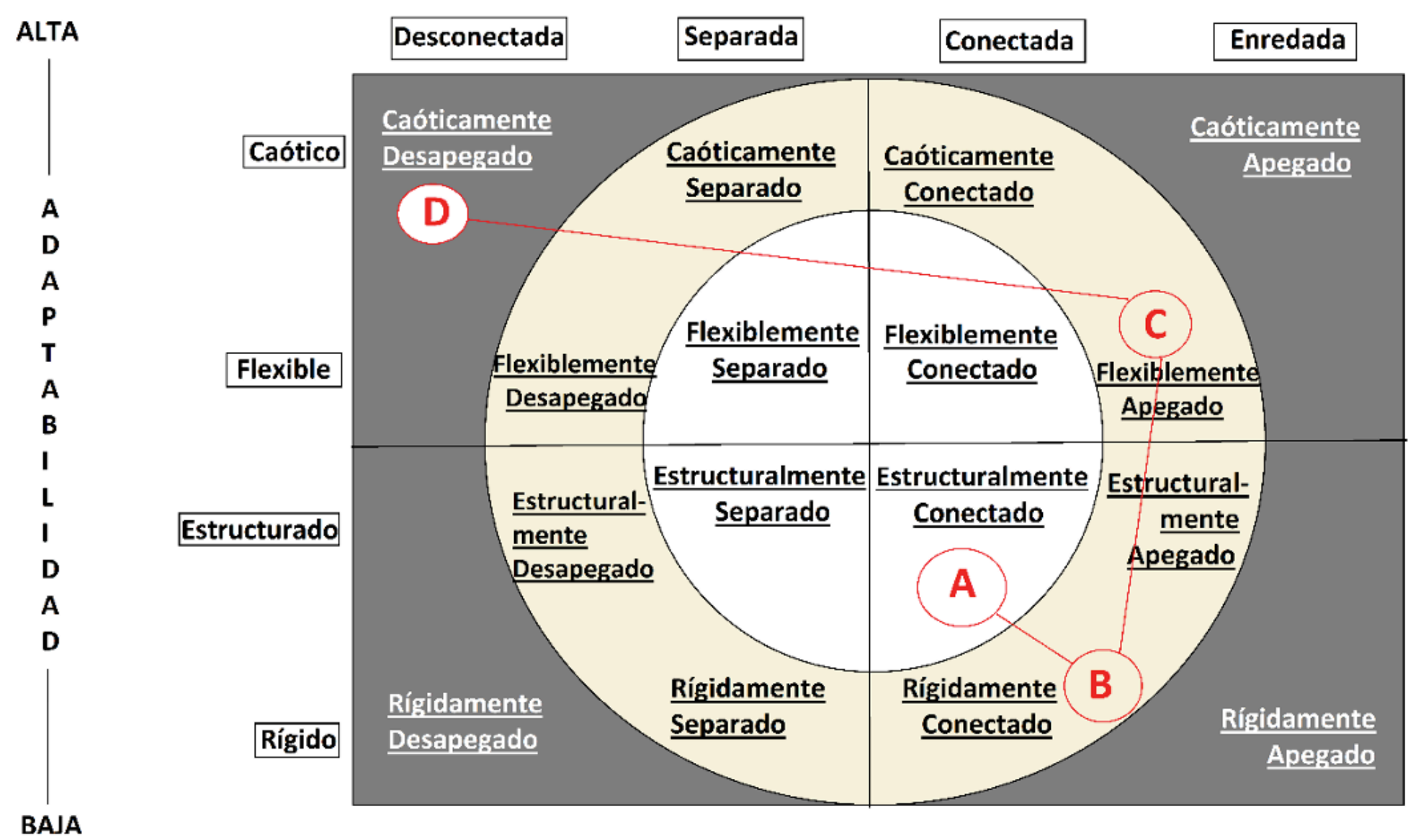

Nota. Elaborado con base en Olson, 2000. 


\section{Referencias}

Acevedo, L., \& Vidal, E. H. (2019). La familia, la comunicación humana y el enfoque sistémico en su relación con la esquizofrenia. Medisan, 23(1), 131-145.

Ahmed, Z., Ahmed, O., Aibao, Z., Hanbin, S., Siyu, L., \& Ahmad, A. (2020). Epidemic of COVID-19 in China and associated Psychological Problems. Asian Journal of Psychiatry, 51(January). https://doi.org/10.1016/j.ajp.2020.102092

Alon, T., Doepke, M., Olmstead-Rumsey, J., \& Tertilt, M. (2019). The Impact of Covid-19 on Gender Equality. National Bureau of Economic Research, 53(9).

Bárcena, A. (2020). Coyuntura, escenarios y proyecciones hacia 2030 ante la presente crisis de Mensajes principales CEPAL. Observatorio COVID-19 En América Latina y El Caribe. http://aneiich.cl/wp-content/uploads/2020/04/Alicia-Barcena-CEPAL-PPTImpacto-COVID-19-en-ALC-3-Abr-2020.pdf.pdf.pdf.pdf

Caccia, P. A., \& Perez, G. (2021). Somatizaciones y Apoyo Social Funcional percibido en el contexto de Aislamiento Social Preventivo y Obligatorio por Covid-19, en Buenos Aires, Argentina. Psicología Unemi, 5(8), 8-18. http://ojs.unemi.edu.ec/index.php/ faso-unemi/article/view/1194

Castro, M. (2007). Tanatología la inteligencia emocional y el proceso de duelo. Trillas.

Cluver, L., Shenderovich, y., Meinck, F., Berezin, M. N., Doubt, J., Ward, C. L., \& Steinert, J. I. (2020). Parenting mental health and economic pathways to prevention of violence against children in South Africa. Social Science \& Medicine, 262(July), 113194.

https://doi.org/10.1016/j.socscimed.2020.113194

D’Aspremont, I., \& Monbourquette, J. (2012). Disculpe, estoy en duelo. Sal Terrae.

Departamento Administrativo Nacional de Estadística. (2021). Estadísticas Vitales. http:// systema74.dane.gov.co/bincol/rpwebengine.exe/portal?lang=esp

Donati, P. (2003). Manual de sociología de la familia (Vol. 1). EUNSA.

Figueroa, H. M. R. (2016). La cremación como ritual funerario y su impacto en el duelo: Una guía para la consejería psicológica. (Tesis doctoral). Universidad del Turabo, Puerto Rico. https://search.proquest.com/openview/b7b70cc408cd62a3c4ca47a1bb2edcdf /1?pq-origsite $=$ gscholar\&cbl $=18750 \&$ diss $=y$

Friedemann, M. (1995). The Framework of Systemic Organization: A Conceptual Approach to families and nursing. T. O. S. Publications.

García, P., Ramírez, E., Guillén, R., \& Sánchez, A. (2016). Salud familiar y enfermería. Manual Moderno. 
García, A. M. (2020). Aproximación al proceso de duelo en tiempos de pandemia. Ponencia. VII International Symposium of the Graduate Nursing Program of the Paulista School of Nursing at Unifesp (Universidad de São Paulo). https://www.researchgate. net/publication/347510473_Aproximacion_al_proceso_de_duelo_en_tiempos_de_ pandemia

Gelder, N., Peterman, A., Potts, A., O’Donnell, M., Thompson, K., Shah, N., \& OerteltPrigione, S. (2020). COVID-19: Reducing the risk of infection might increase the risk of intimate partner violence. EClinicalMedicine, 21, 100348. https://doi. org/10.1016/j.eclinm.2020.100348

González, I. (2000). Las crisis familiares. Revista Cubana de Medicina General Integral, 16(3), 280-286.

Grupo de Investigación en Macroeconomía de la Facultad de Economía de la Universidad de los Andes. (2020). El patrón socioeconómico del COVID-19 en Bogotá. https:// uniandes.edu.co/es/noticias/economia-y-negocios/el-patron-socioconomico-delcovid19-en-bogota

Gustavino, E. P. (1987). Derecho de Familia Patrimonial. Bien de Familia. Tomo I (2a. ed.). Rubinzal y Culzoni.

Hoyos, J. (2020). Mercado laboral - empleo y desempleo julio 2020. https://gestionlegislativa. com/documentos/anexos/COLOMBIA_ECONOMICA_9_31_agosto_Empleo_ julio_2020.pdf

Huang, Y., \& Zhao, N. (2020). Generalized anxiety disorder, depressive symptoms and sleep quality during COVID-19 outbreak in China: a web-based cross-sectional survey. Psychiatry Research Psychiatry, 288(January), 2-3. https://doi.org/10.1016/j. psychres.2020.112954

Instituto Nacional de Medicina Legal y Ciencias Forenses. (2020).Boletín estadísticomensual. https://www.medicinalegal.gov.co/cifras-estadisticas/boletines-estadisticosmensuales

Ko, C. H., Yen, C. F., Yen, J. Y., \& Yang, M. J. (2006). Psychosocial impact among the public of the severe acute respiratory syndrome epidemic in Taiwan. Psychiatry and Clinical Neurosciences, 60(4), 397-403. https://doi.org/10.1111/j.1440-1819.2006.01522.x

Kübler-Ross, E., \& Kessler, D. (2016). Sobre el duelo y el dolor. Luciérnaga. 
Lei, L., Huang, X., Zhang, S., Yang, J., Yang, L., \& Xu, M. (2020). Comparison of Prevalence and Associated Factors of Anxiety and Depression among People Affected by versus People Unaffected by Quarantine during the COVID-19 Epidemic in Southwestern China. Medical Science Monitor, 26, 1-12. https://doi.org/10.12659/MSM.924609

Luo, X. (2020). Gender and Dating Violence Perpetration and Victimization: A Comparison of American and Chinese College Students. Journal of Interpersonal Violence, 36(1112), 5581-5607. https://doi.org/10.1177/0886260518804168

Martínez, J. A., Bolívar, Y., Yanez, L. Y., \& Rey, C. A. (2020). Tendencias de la investigación sobre síntomas de trastornos mentales durante la pandemia por COVID-19. Medicina UPB, 39(2), 24-33. https://doi.org/10.18566/medupb.v39n2.a05

Mazza, M., Marano, G., Lai, C., Janiri, L., \& Sani, G. (2020). Danger in danger: Interpersonal violence during COVID-19 quarantine. Psychiatry Research Journal, 289(January). https://doi.org/10.1016/j.psychres.2020.113046

McCubbin, H. I., \& Patterson, J. M. (1983). The family stress process: The double ABCX model of adjustment and adaptation. Marriage \& Family Review, 6, 7-37.

McPhee, M. D., Keough, M. T., Rundle, S., Heath, L. M., Wardell, J. D., \& Hendershot, C. S. (2020). Depression, Environmental Reward, Coping Motives and Alcohol Consumption During the COVID-19 Pandemic. Frontiers in Psychiatry, 11(October), 1-14. https://doi.org/10.3389/fpsyt.2020.574676

Mejía, L. F. (2020). COVID-19: costos económicos en salud y en medidas de contención para Colombia. Fe de desarrollo, 1, 1-5. https://imgcdn.larepublica.co/ cms/2020/04/07172635/FEDESARROLLO.pdf

Observatorio Colombiano de las Mujeres. (2020). Boletín abril 12 de 2020. Línea 1551 en el contexto de medidas de aislamiento preventivo por Coronavirus en Colombia. https:// mlr.vicepresidencia.gov.co/Documents/15042020--456555329-Boleti-n-III-linea-155-12-04-2020.pdf

Odriozola-González, P., Planchuelo-Gómez, Á., Jesús Irurtia, M., \& Luis-Garcia, R. (2020). Psychological effects of the COVID-19 outbreak and lockdown among students. Psychiatry Research, 290(January), 113180.

Oliva, E., \& Villa, V. J. (2014). Hacia un concepto interdisciplinario de la familia en la globalización. Justicia Juris, 10(1), 11. https://doi.org/10.15665/ri.v10i1.295 
Olson, D. H. (2000). Circumplex Model of Marital and Family Sytems. Journal of Family Therapy, 22(2), 144-167. https://doi.org/10.1111/1467-6427.00144

Organización Panamericana de la Salud. (2020). COVID-19 y violencia contra la mujer. Lo que el sector y el sistema de salud pueden hacer. https://iris.paho. org/bitstream/handle/10665.2/52034/OPSNMHMHCovid19200008_spa. pdf? sequence $=1$ \&isAllowed $=y$

Organización Panamericana de la Salud. (2021). Enfermedades no Transmisibles. https:// www.paho.org/es/temas/enfermedades-no-transmisibles

Ortego, M., \& Alconero, A. (2001). El duelo. Enfermería Científica, 236-237, 46-51. https:// ocw.unican.es/pluginfile.php/1575/course/section/ 2034/tema-11.pdf

Ozamiz-Etxebarria, N., Dosil-Santamaria, M., Picaza-Gorrochategui, M., \& IdoiagaMondragon, N. (2020). Stress, anxiety, and depression levels in the initial stage of the COVID-19 outbreak in a population sample in the northern Spain. Cadernos de Saude Publica, 36(4), 1-10. https://doi.org/10.1590/0102-311X00054020

Ricciulli-Marín, D., Bonet-Morón, J., Pérez-Valbuena, G., Haddad, E., Araújo, I., \& Perobelli, F. (2020). Diferencias regionales en el impacto económico del aislamiento preventivo por el COVID-19: estudio de caso para Colombia. Documentos de Trabajo Sobre Economía Regional y Urbana, 290. https://doi.org/10.32468/dtseru.290

Salazar, C. (2021). El PIB colombiano se contrajo 6,8\% en 2020 y 3,6 en el cuarto trimestre según el Dane. La República. https://www.larepublica.co/economia/siga-aqui-lapublicacion-de-los-resultados-del-dane-del-pib-de-colombia-en-2020-3125471

Salazar, Á. M., Cardozo, Y., \& Escobar, C. (2020). Carga de cuidado de los cuidadores familiares y nivel de dependencia de su familiar. Investigación En Enfermería: Imagen y Desarrollo, 22. https://doi.org/10.11144/Javeriana.ie22.cccf

Sandoval, J. F., \& Hernández, G. (2018). Crítica a la teoría del capital humano, educación y desarrollo socioeconómico. Revista Ensayos Pedagógicos, 13(2), 137-160. https://doi. org/10.15359/rep.13-2.7

Siguenza, W., Buñay, R., \& Guamán-Arias, M. (2017). Funcionamiento familiar real e ideal según el modelo Circumplejo de Olson. Maskana, 8, 77-85. https://publicaciones. ucuenca.edu.ec/ojs/index.php/maskana/article/view/1878 
Tavares, C., de Medeiros, P. M., Silva, I. de A. A., Oliveira, J. V. A., Saraiva, J. S., De Souza, R. I., Lima, C. G., \& Neto, M. L. (2020). The emotional impact of Coronavirus 2019nCoV (new Coronavirus disease). Psychiatry Research, 287. https://doi.org/10.1016/j. psychres.2020.112915

Tomás-Sábado, J. (2020). Miedo y ansiedad ante la muerte en el contexto de la pandemia de la COVID-19. Revista de Enfermería y Salud Mental, 16, 26-30.

Vasquez, F., \& Reyes, G. (2019). Relación existente entre el crecimiento económico, la corrupción y la competitividad global en 20 países latinoamericanos y sus tratados de integración. Espacios, 40(27). http://www.revistaespacios.com/a19v40n27/ a19v40n27p27.pdf

Vences, M. A., Pareja, J., Otero, P., Veramendi-Espinoza, L., Vega-Villafana, M., MogollónLavi, J., Morales, E., Olivera-Vera, J., Salas, L., Triveño, A., Marin, R., Carpio-Rodriguez, R., \& Zafra, J. (2020). Factores asociados a mortalidad en pacientes hospitalizados con COVID-19: Cohorte prospectiva en el Hospital Nacional Edgardo Rebagliati Martins. Scielo Preprints, 1, 1-23. https://doi.org/10.1590/SciELOPreprints.1241

Yang, J., Zheng, Y., Gou, X., Pu, K., Chen, Z., Guo, Q., Ji, R., Wang, H., Wang, Y., \& Zhou, Y. (2020). Prevalence of comorbidities and its effects in coronavirus disease 2019 patients: A systematic review and meta-analysis. International Journal of Infectious Diseases, 94, 91-95. https://doi.org/10.1016/j.ijid.2020.03.017

Zero, O., \& Geary, M. (2020). COVID-19 and Intimate Partner Violence: a call to action. Rhode IslandMedicalJournal,57-59.http://www.rimed.org/rimedicaljournal/2020/06/202006-57-contribution-zero.pdf 


\section{Capítulo 3}

\section{Efecto de la infodemia en la salud mental}

Libia Yanelli Yanez Peñuñuri

Actualmente, el acceso a la información no es el problema, categorizar, sintetizar, discernir, correlacionar sin pretender causalidad, sí que lo es.

Felipe Santoyo Telles

Hoy en día, las redes sociales permiten obtener información de todo tipo, con gran facilidad e inmediatez, lo cual puede ser una gran ventaja; sin embargo, es posible encontrar información inexacta o abundancia de información falsa, que puede generar consecuencias negativas en la conducta de las personas. Por ello, la Organización Mundial de la Salud (OMS, 2020) denomina infodemia a la sobrecarga de información, tanto falsa como verdadera, y su rápida propagación entre las personas y los medios. Este tipo de información puede difundir información errónea en la población y perjudicar la salud física y mental de las personas.

En el caso de la pandemia por COVID-19, por primera vez se ha vivido una emergencia sanitaria a nivel internacional, en la que se emplea la tecnología y las redes sociales para ayudar a las personas a mantenerse informadas. La información está al alcance de todos y esta situación puede ser vista desde una perspectiva positiva por muchos autores. Sin embargo, hay que ser conscientes y tener el suficiente pensamiento crítico para reconocer la información verdadera de la que no es. En ese sentido, una mala información puede generar estigmas, estereotipos y actitudes racistas (e. g., el racismo hacia los asiáticos por ser China el país donde se reportaron los primeros casos de COVID-19). 
De acuerdo con Pantou (2021), la pandemia de COVID-19 ha generado una justificación para aumentar el odio y los prejuicios hacia la población asiática, lo que ha ocasionado las demostraciones de xenofobia y racismo. Incluso, la autora mencionó que en restaurantes de países como Italia o Japón se exhibieron carteles durante la pandemia indicando que las personas de origen chino no podían ser admitidos. En Nueva York, Estados Unidos, algunos autores señalaron que, durante la pandemia de COVID-19, muchos negocios ubicados en la zona de Chinatown cerraron y los ingresos bajaron; en el caso de los restaurantes, debido a la discriminación y estigmatización a la comida proveniente de China. Lo anterior sucedió porque en los inicios de la pandemia, las autoridades de salud refirieron que la enfermedad por COVID-19 fue generada en el mercado de Wuhan, China, donde se venden mariscos y carne salvaje (e. g., carne de murciélago). Posteriormente, algunos informes señalaron que el virus del COVID-19 es casi idéntico a otros tipos de coronavirus transmitidos por murciélagos.

Según Orchard (2021), los ataques xenofóbicos a la población asiática y las actitudes que se han generado en torno a las personas contagiadas de COVID-19 son respuestas irracionales generadas por el miedo. La autora indica que la carencia de información contribuye a estas actitudes negativas; asimismo, las noticias falsas pueden aumentar los prejuicios y la discriminación.

Acerca de la estigmatización por contagio de COVID-19, de acuerdo con el Fondo de las Naciones Unidas para la Infancia (UNICEF, 2020), en su guía para abordar y prevenir el estigma social, cuando existe una nueva enfermedad y poco se conoce de ella, existen muchas interrogantes. Los seres humanos le tememos a lo desconocido y es fácil asociar el miedo y la confusión con la discriminación. Algunas de las acciones que sugieren la UNICEF son priorizar, recopilar y evitar los rumores de información no veraz. No obstante, el Ministerio de Salud de Colombia (2020) refiere que la estigmatización por contagio de COVID-19 puede ocasionar que las personas oculten su enfermedad, por temor a ser discriminado en su ambiente laboral, familiar y social. Además, otra de las consecuencias negativas de la estigmatización es que las personas no busquen atención médica a tiempo y generen comportamientos no saludables. 
Por otra parte, la pandemia de COVID-19 puso en situación de discriminación y de mayor vulnerabilidad a las personas migrantes, debido a la restricción en el acceso de derecho como la salud, la alimentación, la vivienda y el trabajo (Méndez, 2020). A mediados de julio de 2020, casi tres millones de personas estaban varadas sin acceso a la asistencia consular ni a las necesidades básicas, siendo el 16\% de casos registrados en América del sur y central.

Se estima que, en el mundo, hay 281 millones de migrantes internacionales, que equivale al 3.6\% de la población total. Uno de los países con mayor número de casos ha sido Irán que fue golpeada fuertemente por la COVID-19, confirmando más de trece mil casos, aumentando preocupaciones entre la población afgana, lo que ha generado el rechazo y aumento de discriminación en algunos países hacia los migrantes iraníes durante la pandemia de COVID-19 (OMS, 2021).

El bombardeo de información puede provocar un sentimiento de agobio en las personas; si se cree lo que lee o escucha, se puede desequilibrar emocionalmente y sentirse paranoico de tener síntomas de coronavirus, incluso sin tener contacto con alguien enfermo o sin salir de casa; si no se tiene control, puede causar sensaciones como estrés, ansiedad, miedo, tristeza y soledad, lo que aumenta la posibilidad de un diagnóstico de trastorno mental. Esta situación se agrava con el desconocimiento de la duración de la pandemia y la incertidumbre del futuro (De Andrade \& Gómez, 2021; Hernández, 2020;).

La definición de salud mental de la OMS (2018) hace hincapié en el bienestar y la capacidad de "hacer frente al estrés normal de la vida, de trabajar de forma productiva y de contribuir a su comunidad. En este sentido positivo, la salud mental es el fundamento del bienestar individual y del funcionamiento eficaz de la comunidad" (párr.2). Al respecto, hay determinantes sociales que afectan la salud mental como la cultura, el vecindario, la economía y la demografía, haciéndose visible durante el confinamiento y afectando a los que tienen menos recursos. Las consecuencias negativas de la pandemia, como las secuelas tanto físicas como mentales en la población, han afectado emocionalmente a las personas, reactivando trastornos que ya habían padecido o desarrollando otros (Ycaza, 2020). Por ello, se deben realizar acciones para crear entornos y condiciones que permitan a las personas adoptar y mantener una vida saludable (Ribot et al., 2020). 
Durante la pandemia de COVID-19, a través de las plataformas digitales, la población ha estado expuesta a noticias falsas, lo cual ha distorsionado el mundo real y ha generado ansiedad. Por ello, se debe tener cuidado con la información que se comparte, teniendo estrategias para filtrar y evitar noticias falsas (Ministerio de Salud de Perú, 2021). De acuerdo con una encuesta realizada a 26000 niñas de 26 países, casi la mitad (46\%) de ellas aseguró que la información falsa y errónea les ha provocado tristeza, depresión, estrés, preocupación y ansiedad (Omedes, 2021). Además, el miedo al contagio de COVID-19 ha aumentado debido a la sobreabundancia de información de noticias falsas que circulan en los medios de comunicación y redes sociales, lo que pone en peligro la salud de las personas, incluso puede agravar el contagio y provocar la muerte (Perez-Dasilva et al., 2020).

En Perú, en una encuesta realizada a 4009 personas, Mejía et al. (2020) reportaron que el $16 \%$ de los participantes indicaron tener sentimientos de miedo relacionados con la información que circulaba en medios de comunicación y redes sociales. Asimismo, de acuerdo con Nieves-Cuervo et al. (2021), la circulación de mensajes, audios y videos de noticias no verídicas han ocasionado que la población haga caso omiso a las medidas preventivas y que aumentara la angustia, el temor o la indiferencia ante las enfermedades del coronavirus. Ante la poca información acerca de la COVID-19 y el desconocimiento de tratamientos, en las redes sociales empezaron a utilizar remedios caseros que no habían sido evaluados, afirmando que son buenos para la salud; sin embargo, ninguna previene o cura la enfermedad, y no hay evidencia científica que indique que reduzcan el riesgo de contagio, mejoren los síntomas o los cure (Gastañaga, 2020). Incluso era tanta la incertidumbre que se popularizó, en varios países de Latinoamérica, el uso de dióxido de cloro, también llamado "solución mineral milagrosa", como remedio contra el coronavirus; se promocionaron los beneficios para la salud y fue vendida como la cura contra la dolencia, sin tener respaldo científico (Amaya, 2021).

Además del impacto en la salud física y mental, la infodemia ha generado comportamientos sociales negativos durante la pandemia de COVID-19. Se han reportado casos como la quema de un Hospital en Monterrey que atendía a gente diagnosticada con COVID-19, rociando sustancias a las puertas y prendiendo fuego, consumiéndose varias partes, debido a la falta de información de los habitantes que 
no deseaban tener pacientes en el municipio por temor a ser contagiados (Chio, 2020). Asimismo, en el estado de Jalisco se han presentado situaciones de discriminación contra enfermeras, quienes han sido agredidas física y verbalmente en la calle (Infobae, 2020). De la misma manera, en redes sociales se han hecho virales páginas electrónicas que organizan a los pobladores para saquear tiendas y supermercados, rompiendo vidrios y vitrinas para robar productos como pantallas de plasma, celulares, electrodomésticos, deteniendo a más 650 personas, incluyendo menores de edad (El Universal, 2020).

Dado lo anterior, se puede concluir que el miedo y la desinformación aumentan el estigma y la discriminación. Es importante entender que, ante la contingencia actual sanitaria, cualquier persona puede contagiarse de COVID-19, ya que el virus no entiende de clases sociales, etnias, género o edad; por lo tanto, nadie es culpable de enfermarse. Por lo que es de gran importancia promover un comportamiento solidario en la población, evitar la estigmatización y generación de estereotipos, evitar compartir información descontextualizada y verificar las fuentes de información. 


\section{Referencias}

Amaya,A. (2021) Dióxido de cloro, Ivermectina yotrasfalsas curas para combatirel Covid-19.

France24. https://www.france24.com/es/am\%C3\%A9rica-latina/20210303-curasfalsas-covid19-di\%C3\%B3xido-de-cloro-ivermectina

Chio, Y. (06 de abril de 2020). Queman en NL hospital cedido para atender casos de Covid-19. La jornada. https://www.jornada.com.mx/ultimas/estados/2020/04/06/ queman-hospital-en-nl-cedido-a-atender-casos-de-covid-19-6383.html

De Andrade, J., \& Gómez, S. (2021). La infodemia y su alcance en el área psicoemocional de las familias. Un aporte a la crisis de la salud a propósito del Covid-19. Revista Iberoamericana de Ciencia, Tecnología y Sociedad-CTS, 16, 67-82. http://ojs.revistacts. net/index.php/CTS/article/view/202

El Universal. (2020). En la web, llaman a saquear tiendas. https://www.eluniversal.com. $\mathrm{mx} / \mathrm{metropoli/edomex/en-la-web-llaman-saquear-tiendas}$

Fondo de las Naciones Unidas para la Infancia. (2020). El estigma social asociado a COVID-19. http://www.cruzrojacolombiana.org/wp-content/uploads/2020/03/COVID19Stigma-guia-2002-Esp.pdf

Gastañaga, M. (2020) Remedios caseros contra el covid-19: más mitos que verdades. Instituto Nacional de Salud. https://web.ins.gob.pe/es/prensa/noticia/remedioscaseros-contra-el-covid-19-mas-mitos-que-verdades

Hernández, J. (2020). Impacto de la COVID-19 sobre la salud mental de las personas. Medicentro Electrónica, 24(3), 578-594. http://scielo.sld.cu/scielo.php?script=sci_ arttext\&pid=S1029-30432020000300578\&lng=es\&tlng=es

Infobae. (2020). Bajan del transporte a enfermeras en Jalisco y les rocían cloro por miedo a contagios de Covid-19. https://www.infobae.com/america/mexico/2020/03/31/ bajan-del-transporte-a-enfermeras-en-jalisco-y-les-rocian-cloro-por-miedo-acontagios-de-covid-19/

Mejía, C. R., Rodriguez-Alarcon, J. F., Garay-Rios, L., Enriquez-Anco, M., Moreno, A., Huaytán-Rojas, K., Huancahuari-Ñañacc Huari, N., Julca-Gonzales, A., Alvarez, C. H., Choque-Vargas, J., \& Curioso, W. H. (2020). Percepción de miedo o exageración que transmiten los medios de comunicación en la población peruana durante la pandemia de la COVID-19. Revista Cubana de Investigaciones Biomédicas, 39(2), e698. http:// scielo.sld.cu/scielo.php?script=sci_arttext\&pid=S0864-03002020000200001\&lng=e s\&tlng=es 
Méndez, M. (Coord.). (2020). Informe sobre los efectos de la pandemia de covid-19 en las personas migrantes y refugiadas. http://cmdpdh.org/project/informe-sobre-losefectos-de-la-pandemia-de-covid-19-en-las-personas-migrantes-y-refugiadas/

Ministerio de Salud de Colombia. (2020). Estigma social asociado a COVID 19. https:// coronaviruscolombia.gov.co/Covid19/docs/aislamiento-saludable/salud-mental/ centro-de-documentos/categoria2/estigma_asociado_al_covid19_2020.pdf

Ministerio de Salud de Perú. (2021). Las fake news generan estrés, ansiedad y aumentan la violencia en jóvenes y adolescentes. Gobierno de Perú. https://www.gob.pe/institucion/ minsa/noticias/500916-las-fake-news-generan-estres-ansiedad-y-aumentan-laviolencia-en-jovenes-y-adolescentes

Nieves-Cuervo, G. M., Manrique-Hernández, E. F., Robledo-Colonia, A. F., \& Grillo, A. (2021). Infodemia: noticias falsas y tendencias de mortalidad por COVID-19 en seis países de América Latina. Revista Panamericana de Salud Publica, 45, e44. https://doi. org/10.26633/RPSP.2021.44

Orchard, M. (2021). Estigma, rechazo y discriminación a pacientes con COVID-19: respuestas al miedo a una enfermedad desconocida. https://coes.cl/prensa-estigma-rechazo$\mathrm{y}$-discriminacion-a-pacientes-covid-19-respuestas-al-miedo-a-una-enfermedaddesconocida/

Omedes, E. (2021). Ansiedad, depresión o estrés: los efectos que sufren casi la mitad de las niñas y adolescentes a causa de las 'fake news'. 20 Minutos. https://www.20minutos. es/noticia/4845337/0/efectos-ninas-adolescentes-desinformacion-fake-newsinforme/

Organización Mundial de la Salud. (2018). Salud mental:fortalecer nuestra respuesta. https:// www.who.int/es/news-room/fact-sheets/detail/mental-health-strengthening-ourresponse

Organización Mundial de la Salud. (2020). Gestión de la infodemia sobre la COVID-19: Promover comportamientos saludables y mitigar los daños derivados de la información incorrecta y falsa. https://www.who.int/es/news/item/23-09-2020-managing-thecovid-19-infodemic-promoting-healthy-behaviours-and-mitigating-the-harmfrom-misinformation-and-disinformation

Organización Mundial de la Salud. (2021). La COVID-19 deja desamparados y sin ayuda a los migrantes y refugiados. https://news.un.org/es/story/2021/04/1490622 
Pantou Y. (2021). Ser asiático en la época de COVID-19. Teología y cultura, 18(23) 79-83. Pérez-Dasilva, J.-A., Meso-Ayerdi, K., \& Mendiguren-Galdospín, T. (2020). Fake news y coronavirus: detección de los principales actores y tendencias a través del análisis de las conversaciones en Twitter. Profesional de la Información, 29(3), 1-22. https:// doi.org/10.3145/epi.2020.may.08

Ribot, V. C., Chang, N., \& González, A. L. (2020). Efectos de la COVID-19 en la salud mental de la población. Revista Habanera de Ciencias Médicas, 19(Sup. 1). http://scielo.sld. cu/pdf/rhcm/v19s1/1729-519X-rhcm-19-s1-e3307.pdf

Ycaza, D. (2020). La importancia de la salud mental durante la pandemia. Panama Digital. https://www.panamadigital.gob.pa/Noticia/la-importancia-de-la-salud-mentaldurante-la-pandemia 


\section{Capítulo 4}

\section{Exposición de violencia por conflictos armados (narcotráfico) y estrés postraumático durante la pandemia de COVID-19}

Alexia Maytee Campas Urias, Libia Yanelli Yanez Peñuñuri

y Marcela Cáñez Navarrete

La violencia ha sido definida por la Organización Mundial de la Salud (OMS) como el uso premeditado de la fuerza, ejercida o en grado de amenaza, contra uno mismo, otro sujeto o un grupo o comunidad, "que cause o tenga muchas probabilidades de causar lesiones, muerte, daños psicológicos, trastornos del desarrollo o privaciones" (Ministerio de Sanidad, Consumo y Bienestar Social, s.f., párr.1).

Un tipo de violencia es la colectiva, la cual es definida por la OMS como:

El uso instrumental de la violencia por gente que se identifica a sí misma como miembros de un grupo, ya sea transitorio o de larga duración, contra otro grupo, sea real o imaginado con el fin de conseguir determinados objetivos políticos, económicos y sociales. (Larisgoitia et al., 2009, párr.1)

Este tipo de violencia puede adoptar conflictos armados como el narcotráfico; el concepto de narcotráfico comprende las actividades criminales relacionada con el tráfico de drogas; por lo que incluye "la producción, la transportación, el tráfico y el comercio de narcóticos prohibidos por las leyes penales y de salud en México" (Núñez \& Espinoza, 2017, p.96). Respecto a los conflictos armados, estos refieren a: 
todo enfrentamiento protagonizado por grupos de diferente índole (tales como fuerzas militares regulares o irregulares, guerrillas, grupos armados de oposición, grupos paramilitares, o comunidades étnicas o religiosas que, utilizando armas u otras medidas de destrucción, provocan más de 100 víctimas en un año. (Cañadas et al., 2005, como se citó en Rocha et al., 2017, p.9)

\section{Conflictos armados por narcotráfico en Caborca, Sonora}

En los últimos años, la disputa de las plazas en Caborca ha generado altas tasas de homicidio en la región; los homicidios han crecido un 40\% aproximadamente (El Universal, 2020; Sumano, 2021). Por su ubicación geográfica, la ciudad de Caborca, Sonora, colinda con la frontera de Arizona en Estados Unidos. En ese sentido, según Aguirre (2017), la frontera con Arizona es propicia para el tráfico de drogas, debido a que cuenta con diferentes cruces fronterizos y aduanas. Además, el estado de Sonora es caracterizado como un punto de intersección, en el que se encuentran tres de los mayores cárteles del país: el cártel de Sonora, el de Ciudad Juárez y el de Tijuana. Sin embargo, durante el año 2020 y primeros meses del 2021, en el estado de Sonora se han manifestado disputas por organizaciones delictivas y cárteles del narcotráfico como el Cártel de Sinaloa, "Los Chapitos", "Los Salazar" (facción del Cártel de Sinaloa), el Cártel Jalisco Nueva Generación, así como remanentes del cártel de los Beltrán Leyva.

Algunos autores refieren que la pandemia del COVID-19 ha impactado de manera negativa a diferentes sectores de la población como el caso de la salud, educación y economía. En el caso de los cárteles mexicanos, Pastor (2020) mencionó que uno de los problemas a los que se enfrenta el narcotráfico durante la pandemia de COVID-19 es el abastecimiento relacionado con fentalino; este se obtiene como la metanfetamina, que procede de China, esencialmente de Wuhan, lugar donde comenzó la pandemia de COVID-19. Asimismo, con la falta de fentalino, la cantidad de droga que se exporta a Estados Unidos es menor, sumado a que las fronteras del mundo se encuentran cerradas. Por tal motivo, durante la pandemia, se han relacionado otras fuentes ilegales de financiamiento de los cárteles como robo de combustible, extorsión, robos, secuestro, rapto de mujeres, cobro de derecho de renta o piso a los comerciantes; lo anterior, ha provocado un aumento de la violencia. 
De acuerdo con la OMS (2018), la importancia del contexto social y cultural es muy importante para el desarrollo de los individuos y la forma en la que contribuyen con la comunidad, como se menciona en la definición de salud mental:

La salud mental es un estado de bienestar en el que la persona realiza sus capacidades y es capaz de hacer frente al estrés normal de la vida, de trabajar de forma productiva y de contribuir a su comunidad. En este sentido positivo, la salud mental es el fundamento del bienestar individual y del funcionamiento eficaz de la comunidad. (OMS, 2018, párr.2)

$\mathrm{Al}$ respecto, la exposición a un evento traumático podría generar un trastorno mental como lo es el estrés postraumático (TEPT), el cual: "es el único trastorno mental al que se le puede adjudicar una causa específica, en este caso la exposición a un evento o situación traumática" (Vargas \& Coria, 2017, p.15). Como es el caso de la violencia, en el que una persona cuando ha estado expuesta de manera directa o indirecta a un evento de amenaza se puede desarrollar un TEPT. Los síntomas pueden incluir recuerdos recurrentes, sueños angustiosos, pensamientos o imágenes molestas sobre el evento traumático.

Por lo anterior, se hace referencia a la importancia de estudiar el efecto de la violencia por conflictos armados (narcotráfico) en la salud mental de los jóvenes, como es el caso de la generación de trastornos mentales como el TEPT.

Por lo tanto, el objetivo del presente capítulo es describir la exposición de violencia por conflictos armados (narcotráfico) y su relación con el estrés postraumático en jóvenes estudiantes de Caborca, Sonora, México durante la pandemia de COVID-19.

Los objetivos específicos son los siguientes:

- Conocer la frecuencia con la que las personas han sido heridas como consecuencia de un acto de violencia de narcotráfico en la región de Caborca, Sonora.

- Conocer la frecuencia con la que las personas de un familiar o persona cercana haya sido herido de un acto de violencia por narcotráfico en la región de Caborca, Sonora. 
- Describir el tipo de exposición de violencia por conflictos armados (narcotráfico) en Caborca, Sonora.

- Describir el tipo de exposición de violencia por conflictos armados (narcotráfico) que han sido víctimas familiares y conocidos en Caborca, Sonora.

- Describir la prevalencia de estrés postraumático en los participantes.

- Analizar la relación entre las personas que han sido heridas como consecuencia de un acto de violencia de narcotráfico en la región de Caborca, Sonora y estrés postraumático.

- Analizar la relación entre las personas que han tenido un familiar o persona cercana herido como consecuencia de un acto de violencia de narcotráfico en la región de Caborca, Sonora y estrés postraumático.

\section{Método}

El tipo de diseño fue no experimental transversal de tipo correlacional (Hernández et al., 2014). Se incluyeron un total de 317 participantes, jóvenes universitarios estudiantes entre 18 y 30 años que vivieran en la zona del desierto (Caborca, Puerto Peñasco, San Luis Río Colorado y General Plutarco Elías Calles) y Río Altar (Altar, Átil, Oquitoa, Pitiquito, Sáric y Tubutama).

\section{Instrumentos}

Experiencias de situaciones estresantes con los grupos armados (narcotráfico) durante el último año en la Ciudad de Caborca Se evaluaron las experiencias directas o indirectas, en situaciones violentas relacionadas con grupos armados y síntomas de trauma con una escala tipo Likert con las siguientes opciones de respuesta: totalmente de acuerdo, de acuerdo, desacuerdo, totalmente en desacuerdo. La confiabilidad total fue de .83 .

Escala de Gravedad de Síntomas del Trastorno de Estrés Postraumático (Echeburúa et al., 1997) Es un instrumento breve que evalúa síntomas de estrés postraumático. Cuenta con 17 ítems, basados en los criterios del DSM-IV para evaluar el trastorno de estrés postraumático en una escala de 0 a 3 en escala Likert, según la frecuencia e intensidad de los síntomas. El cuestionario cuenta con estabilidad temporal y confiabilidad. 


\section{Procedimiento}

Se solicitaron los permisos a las autoridades para la aplicación del instrumento a los directivos, coordinadores de programa y alumnos de la Universidad de Sonora, Campus Caborca. Una vez autorizados los permisos, se procedió a la aplicación de los cuestionarios a través de Google Forms. Se solicitaron consentimientos informados y la participación fue voluntaria.

\section{Análisis de datos}

Los datos fueron importados del programa de Microsoft Forms al programa SPSS 23. Luego, se llevó a cabo una limpieza de datos y se realizaron análisis de estadística descriptiva, análisis de frecuencia y porcentaje. Se llevaron a cabo pruebas de normalidad de Shapiro-Wilk y Kolmorov-Smirnov, se realizaron pruebas de U de Mann-Whitney y se analizó la probabilidad de superioridad para evaluar el tamaño del efecto.

\section{Resultados}

En la Tabla 1 se muestra la frecuencia de haber sido herido como consecuencia de un acto de violencia de narcotráfico en la región. Se observa que cinco personas han sido heridas (1.6\%).

\section{Tabla 1}

Ha sido herido como consecuencia de un acto de violencia de narcotráfico en la región

\begin{tabular}{ccc}
\hline Respuesta & $\mathbf{n}$ & $\mathbf{\%}$ \\
\hline No & 316 & 98.4 \\
\hline Sí & 5 & 1.6 \\
\hline
\end{tabular}

En la Tabla 2 se muestra la frecuencia de que un familiar o persona cercana haya sido herido como consecuencia de un acto de violencia armada por la disputa de plaza del narcotráfico en la región. Se encontró que 118 personas (36.8\%) fueron heridas. 


\section{Tabla 2}

¿Alguien cercano a ti fue herido como consecuencia de un acto de violencia armada por la disputa de plaza del narcotráfico en la región?

\begin{tabular}{ccc}
\hline Respuesta & $\mathbf{n}$ & $\mathbf{\%}$ \\
\hline No & 203 & 63.2 \\
\hline Sí & 118 & 1.6 \\
\hline
\end{tabular}

En la Figura 1 se muestra a qué tipo de violencia por conflictos armados (narcotráfico) han estado expuestos los encuestados, en Caborca, Sonora.

\section{Figura 1}

Durante el último año ¿a qué tipo de situaciones relacionadas con grupos armados has estado expuesto?

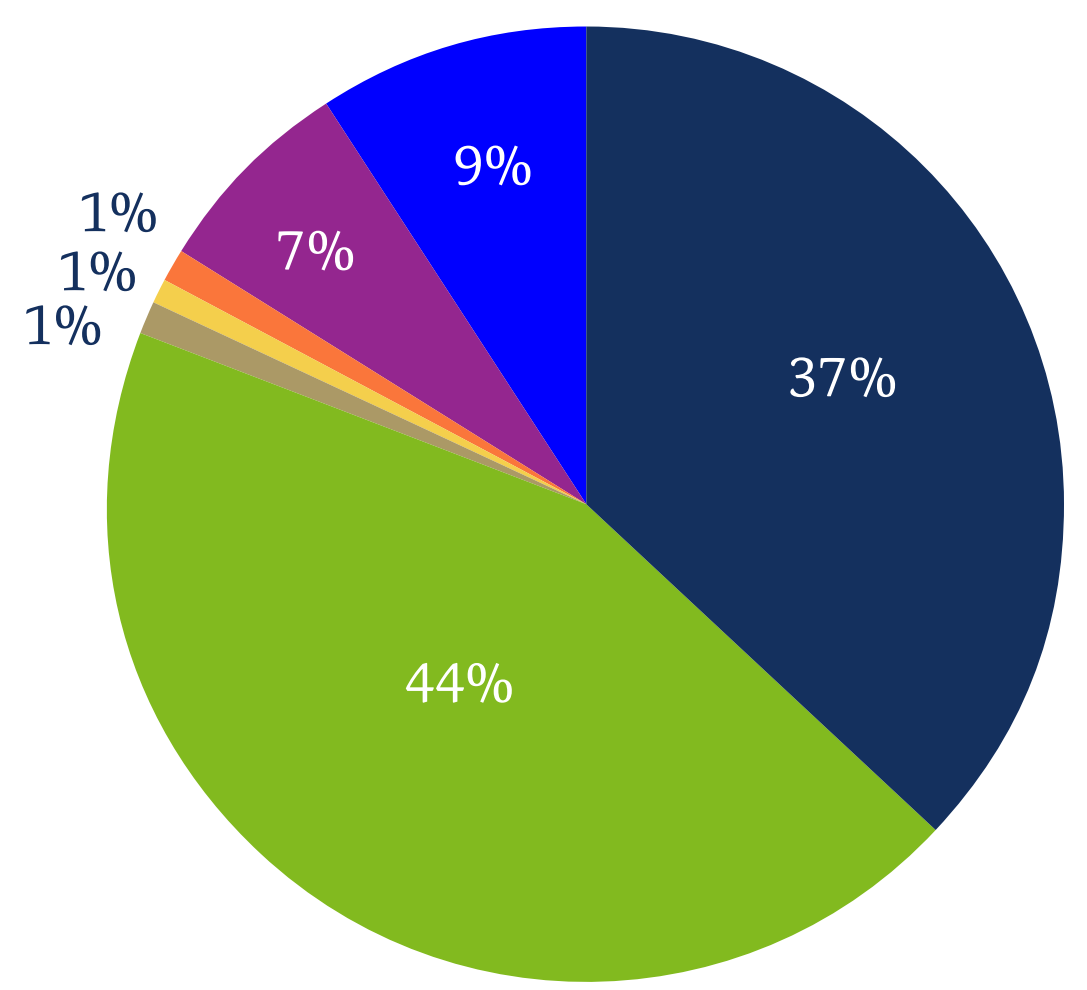

Contacto cercano con víctimas

Enfrentamientos armados

Escuchar detonaciones cercanas

Gente armada
Heridas graves

Muertes violentas, asesinatos o matanzas

Ninguna de las anteriores

Movilización de sicarios 
Como se puede observar en la Figura 1, el 44\% de los participantes ha sido expuesto a enfrentamientos armados, seguido del $37 \%$ que ha tenido contacto con víctimas o familiares que han experimentado hechos violentos relacionados con el narcotráfico en Caborca, Sonora. El 9\% de los jóvenes reportó no haber sido expuesto a algún hecho violento, mientras que el $7 \%$ ha sido expuesto a muertes violentas, asesinatos o matanzas.

Respecto al tipo de violencia por conflictos armados (narcotráfico), de los cuales han sido víctimas familiares y conocidos en Caborca, Sonora, en la Figura 2 se muestran los resultados.

\section{Figura 2}

Durante el último año, ¿algún familiar o conocido ha estado expuesto a situaciones relacionadas con grupos armados? ¿cuáles?

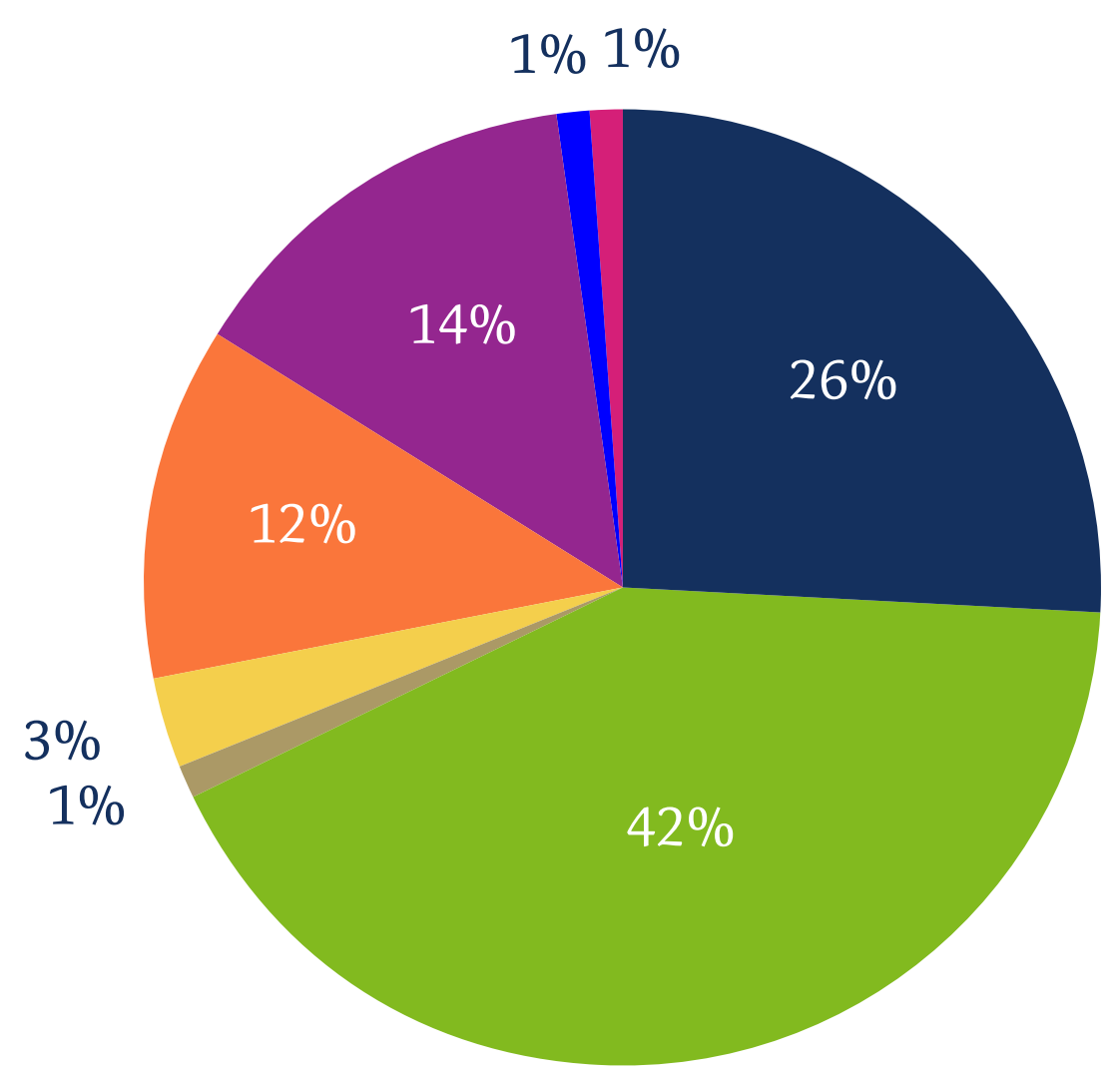

Contacto cercano con víctimas

Enfrentamientos armados

Gente armada

Heridas graves
Muertes violentas, asesinatos o matanzas

Ninguna de las anteriores

Amenazas

Amputaciones o fragmentaciones de cuerpos 
El 42\% mencionó que alguno de los familiares o conocidos de los participantes ha sido expuesto a enfrentamientos armados, el $26 \%$ ha tenido contacto con víctimas o familiares que han experimentado hechos violentos, el $14 \%$ no ha estado en contacto con familiares o víctimas de violencia por conflictos armados. Mientras que el $12 \%$ de los familiares o personas cercanas ha estado expuesto a muertes violentas, asesinatos o matanzas.

En referencia a la prevalencia del estrés postraumático en los participantes, se encontró que el 53.6\% presenta estrés relacionado con los eventos violentos del narcotráfico en la región.

Respecto a la relación entre la exposición a violencia por conflicto armado (narcotráfico) y el estrés postraumático, se encontraron diferencias estadísticamente significativas (Tabla 3).

\section{Tabla 3}

Diferencias entre haber sido herido como consecuencia de un acto de violencia de narcotráfico en la región y estrés

\section{Estrés postraumático}

\begin{tabular}{lccccc}
\hline & Sin estrés & Con estrés & U & P & PSest \\
\hline $\begin{array}{l}\text { Haber sido herido como } \\
\begin{array}{l}\text { consecuencia de un conflicto } \\
\text { armado (narcotráfico) }\end{array}\end{array}$ & 158.59 & 216.50 & 7963.500 & $.000^{\star * *}$ & .33 \\
\hline $\begin{array}{l}\text { Un familiar o persona } \\
\begin{array}{l}\text { cercana ha sido herida como } \\
\text { consecuencia de un conflicto } \\
\text { armado (narcotráfico) }\end{array}\end{array}$ & 142.85 & 187.72 & 8470.500 & $.000^{\star * *}$ & .35 \\
\hline
\end{tabular}

Nota. $\mathrm{U}=\mathrm{U}$ de Mann-Whitney; PSest = Probabilidad de superioridad (tamaño del efecto). ${ }^{*} p<.05 ;{ }^{* *} p<.01 ;{ }^{* * *} p<.001$. 


\section{Discusión}

El objetivo del presente trabajo fue describir la exposición de violencia por conflictos armados (narcotráfico) y su relación con el estrés postraumático en jóvenes estudiantes de Caborca, Sonora, México durante la pandemia de COVID-19.

La Encuesta Nacional de Victimización y Percepción sobre Seguridad Pública (ENVIPE) (INEGI, 2021) arrojó que alrededor de 21.2 millones de personas fueron expuestas a la violencia por conflicto armado durante el 2020; además, que el 28.4\% de las viviendas en México cuenta con una integrante víctima del delito, lo cual representa 23520 víctimas por cada 100 mil habitantes. En el caso de la presente investigación, por primera vez se reportan datos en la región de Caborca, Sonora, del impacto de la exposición de violencia por pelea de plazas de narcotráfico y el impacto negativo que puede llegar a tener en la salud mental de la población.

Por otro lado, los resultados de este estudio coinciden con la investigación de Flores y Atuesta (2018), quienes encontraron una relación entre los trastornos mentales (i. e., depresión, ansiedad y estrés postraumático) y la violencia relacionada con las drogas. Los autores mencionaron la importancia de desarrollar estrategias de salud mental para poder reducir los síntomas depresivos en la población.

Es importante considerar que las personas con algún diagnóstico de trastorno mental relacionado con síntomas de estrés como TEPT y la situación de violencia e inseguridad relacionada con el narcotráfico en la región pueden desencadenar otros tipos de trastornos relacionados con la ansiedad o depresión.

Para futuros estudios es recomendable la creación de instrumentos de medición de la violencia, específicamente por conflictos armados de narcotráfico. Asimismo, es importante considerar otras variables relacionadas como la ansiedad o la depresión, en distintas etapas del desarrollo como en niños o adultos mayores. 


\section{Referencias}

Aguirre, M. P. (2017). Aproximaciones a la violencia estatal en Sonora: el Estado el crimen y la ubicación estratégica. http://bibliodigitalibd.senado.gob.mx/ bitstream/handle/123456789/3974/Perez\%20Aguirre\%20\%281\%29. pdf? sequence $=1 \&$ isAllowed $=y$

Echeburúa, E., del Corral, P., Amor, P. J., Zubizarreta, I., Sarasua, B. (1997). Escala de Gravedad de Síntomas del Trastorno de Estrés Postraumático: Propiedades psicométricas. Análisis y Modificación de Conducta, 23(90), 503-526.

El Universal. (2020). Hijos del "Chapo" y Cártel de Caro Quintero desatan guerra en desierto de Sonora. https://www.eluniversal.com.mx/estados/hijos-del-chapo-y-cartel-decaro-quintero-desatan-guerra-en-desierto-de-sonora

Flores, I., \& Atuesta, L. E. (2018). La "guerra contra las drogas" y la salud mental: efectos sobre la población general. CIDE. https://politicadedrogas.org/ documentos/20180308_093836_salud_mental_final_7_marzo.pdf

Hernández, R., Fernández, C., \& Baptista, P. (2014). Metodología de la Investigación. McGraw-Hill.

Instituto Nacional de Estadística y Geografía. (2021). Encuesta Nacional de Victimización Prevalencia sobre Seguridad Pública. Comunicado de prensa Núm. 5321/21. https://www.inegi.org.mx/contenidos/saladeprensa/boletines/2021/EstSegPub/ envipe2021.pdf

Larisgoitia, I., Izarzugaza, I., Markez, I., Fernández, I., Iraugi, I., Ballesteros, J., Alonso, J., Fernández, A., Moreno, F., \& Retolaza, A. (2009). La noche de las víctimas. Fundación Fernando Buesa Blanco.

Ministerio de Sanidad, Consumo y Bienestar Social. (s.f.). Violencia y salud. https://www. mscbs.gob.es/ciudadanos/violencia/violenciaSalud/home.htm

Núñez, G., \& Espinoza, C. E. (2017). El narcotráfico como dispositivo de poder sexogenérico: crimen organizado, masculinidad y teoría queer. Revista interdiciplinaria de estudios de género de El Colegio de México, 3(5), 90-128. http://www.scielo.org.mx/ $\mathrm{pdf} / \mathrm{riegcm} / \mathrm{v} 3 \mathrm{n} 5 / 2395-9185-$ riegcm-3-05-00090.pdf

Organización Mundial de la Salud. (2018). Salud mental:fortalecer nuestra respuesta. https:// www.who.int/es/news-room/fact-sheets/detail/mental-health-strengthening-ourresponse 
Pastor, M. L. (2020).El coronavirus golpealasfinanzasdelos cárteles mexicanos [Documento informativo]. Instituto Español de Estudios Estratégicos. https://www.ieee.es/Galerias/ fichero/docs_informativos/2020/DIEEEI15_2020LUIPAS_COVIDMexico.pdf

Rocha, D., Rodríguez, M. A., \& Rozo, A. M. (2017). Trauma por violencia en contextos de violencia sociopolítica: una revisión sistemática (Trabajo de grado). Pontificia Universidad Javeriana, Bogotá, D.C. https://repository.javeriana.edu.co/ bitstream/handle/10554/22140/Daniela\%20Rocha,\%20Mar\%C3\%ADa\%20 Rodr\%C3\%ADguez,\%20Ana\%20Rozo,\%202017.pdf?sequence=1

Sumano, J. A. (2021, 26 de julio). Crimen organizado y violencia en Sonora. Nexos. https:// seguridad.nexos.com.mx/crimen-organizado-y-violencia-en-sonora/

Vargas, A., \& Coria, K. (2017). Estrés postraumático: tratamiento basado en la terapia de aceptación y compromiso. El Manual Moderno. 


\title{
Capítulo 5
}

\section{Factores que influyen en las alteraciones de sueño durante la pandemia de COVID-19}

\author{
Linda Isis García Estrada
}

El sueño es considerado una necesidad primaria y un ciclo vital biológico que se presenta en el ser humano. El sueño es un estado conductual, que se presenta con periodicidad circadiana y tiene grados de profundidad. Se asocia con la inmovilidad y la relajación muscular (Espinosa \& Manosalva, 2020; Velayos et al., 2007). Según Álvarez et al. (2020), este aparece por fases, las cuales son: (1) vigilia, (2) sueño profundo sin movimientos oculares y (3) sueño profundo con movimientos oculares rápido.

La fase 1 del sueño, normalmente, se caracteriza porque es el estado inicial del funcionamiento, con tono muscular y actividad ocular. La fase 2 comprende tres etapas: en la primera etapa disminuyen los movimientos oculares y la actividad muscular; en la segunda etapa aparecen los husos, conocido como ráfagas en la actividad cerebral; y en la tercera etapa, igual que las anteriores, ya no hay movimientos oculares y toda la actividad muscular está disminuida. En la fase 3, conocida como sueño de movimientos oculares rápidos (MOR), no hay nada de actividad muscular y los movimientos de los ojos son rápidos; como mencionan varios autores (Cobacango et al., 2019; González et al., 2018) aquí se producen las ensoñaciones.

Estudios realizados por la Sociedad Norteamericana de Cáncer revelan que la media del sueño de la población es entre 8 y 9 horas. En las últimas décadas, el sueño ha disminuido aproximadamente dos horas de las ocho horas habituales que se sugiere dormir (Fontana et al., 2014), repercutiendo así en la calidad de sueño, que nos proporciona bienestar físico y mental. 


\section{Calidad de sueño}

La calidad de sueño tiene como definición una dimensión muy amplia y compleja, además de ser un funcionamiento básico de la persona, donde se comprende aspectos cuantitativos y cualitativos de bienestar y funcionamiento diurno. La función principal del sueño es mejorar el rendimiento físico y mental de la persona (Bornhausen et al., 2018). El Îndice de Calidad de Sueño de Pittsburgh (ICSP) (Jiménez-Genchi et al., 2008) proporciona una puntuación global de la calidad del sueño (Sierra et al., 2002), los componentes que se evalúan en el ICSP son siete: calidad del sueño, latencia del sueño, duración del sueño, eficiencia del sueño, perturbaciones del sueño, uso de medicación y disfunción diurna (Buysse et al., 1989).

\section{Confinamiento por pandemia de COVID-19}

La enfermedad por coronavirus 2019 (COVID-19), provocada por el virus SARSCoV-2, apareció por primera vez entre el 12 y 19 de diciembre de 2019 en Wuhan, China (Huang \& Zhao, 2020). Posteriormente, el 31 de diciembre de 2019, la Organización Mundial de la Salud (OMS) reportó los casos de COVID-19 a nivel internacional y el 11 de marzo de 2020 se declaró pandemia global, por lo que muchos países decretaron un periodo de confinamiento prorrogable (Cabrera, 2020). Por esta razón, para poder lograr una inmunidad colectiva ${ }^{1}$ contra la COVID-19, la OMS apoyó la postura de lograrlo por medio de la vacunación; mientras tanto, deben tomarse medidas de distanciamiento físico, restricción de desplazamiento aplicada en gran escala y el confinamiento para desacelerar la transmisión de la enfermedad (OMS, 2020).

Al respecto, Ramírez-Ortiz et al. (2020) explicaron que el confinamiento en casa produce efectos negativos, donde se experimentan grandes cambios e interrupciones en las rutinas, afectando la cantidad de horas para dormir. Y una mala calidad de sueño afecta tanto el rendimiento motor como el cognitivo, el estado de ánimo e incluso aspectos metabólicos, ya que en el sueño hay una recuperación física y mental (Failoc-Rojas et al., 2015).

1 Que refiere a "la protección indirecta contra una enfermedad infecciosa que se consigue cuando una población se vuelve inmune, ya sea como resultado de la vacunación o de haber presentado la infección con anteriroridad" (OMS, 2020, párr.1). 


\section{Consecuencias de mala calidad de sueño durante la pandemia de COVID-19}

Un gran número de personas presentan alteraciones del sueño en la sociedad actual, "donde los avances tecnológicos constituyen un factor muy importante en disminuir las horas dormidas" (Contreras, 2013, p.341). Además, los cambios en la organización familiar, rutinas laborales, aislamientos sociales y el confinamiento indujeron sentimientos de desamparo, abandono, soledad, insomnio e ira (Pinto et al., 2020).

Un estudio que se realizó en Italia durante la pandemia de COVID-19 en adultos de 18 a 89 años, donde la mayoría era mujer (74.6\%), reveló que el 57.1\% de los encuestados experimentaron mala calidad de sueño y niveles altos de ansiedad y angustia; lo cual afectó la calidad de vida y el estado de salud (Casagrande et al., 2020).

En otro estudio realizado en Bangladesh a estudiantes universitarios durante la pandemia de COVID-19, se mencionó que aproximadamente el 27\% de los universitarios informaron tener una mala calidad del sueño, ansiedad, depresión y miedo a la COVID-19; por lo cual, se recomendó implementar programas destinados a fortalecer el estado de salud mental, así como una unidad de asesoramiento psicológico en las universidades (Ahammed et al., 2021).

En China, el 18\% de la población adulta reportó mala calidad de sueño. Los trabajadores de la salud tenían más probabilidades de informar mala calidad de sueño, siendo más propensos al estrés crónico y angustia psicológica (Huang \& Zhao, 2020).

En la investigación realizada por Ramírez-Ortiz et al. (2020), en Colombia, se encontró que existen factores sociales y psicológicos que han impactado en la calidad de sueño durante la pandemia de COVID-19 (Tabla 1). Los autores señalaron que algunos de estos factores son: la disminución a la exposición de luz solar, debido al encierro por confinamiento; los cambios en la dieta, manteniendo alto niveles de consumo; la reducción de la interacción social, ya que se mantenía distancias entre individuos; el aumento de horas de trabajo bajo circunstancias estresante, por el hecho de tener que tomar nuevos protocolos y adaptarse a la nueva normalidad; y la incertidumbre e inseguridad sobre el estado de salud de uno mismo y de los seres queridos. 
Algunos factores sociales y psicológicos que impactan en la calidad de sueño durante la pandemia de COVID-19 es la disminución en la exposición a la luz solar, los cambios en la dieta, la reducción de la interacción social, trabajar más horas bajo circunstancias estresantes y vivir con la incertidumbre e inseguridad sobre el estado de salud (Ramírez et al., 2020).

Por otra parte, Castillo et al. (2020) realizaron un estudio considerando la población de estudiantes de la Universidad Tecnológica de Panamá, donde se aplicó una encuesta con el estilo de muestreo bola de nieve. Se investigó el efecto de la privación del sueño. De acuerdo con sus hallazgos, las personas que no duermen bien durante una noche, al día siguiente se pueden sentir cansados e irritados, pero no dañarán su salud. No obstante, si las personas continúan con la privación del sueño durante varios días, esto podría afectar su salud.

De acuerdo con Live Well (como se citó en Catillo et al., 2020), algunas enfermedades que son el resultado de no dormir bien son: (a) diabetes, (b) enfermedades cardiacas, (c) aumento de los cambios metabólicos y (d) mayor riesgo de depresión.

En un estudio realizado en Caborca, Sonora, durante la pandemia de COVID-19, participaron 100 mujeres estudiantes de la Universidad de Sonora de edades de 1827 años; en este se analizó la relación de calidad de sueño y estrés, identificándose un alto índice de estrés en los participantes (49\%) y altos índices en el componente de duración de calidad de sueño (28\%); además, se encontró una estrecha relación de calidad de sueño y estrés, resultando deficiencia y poca calidad de sueño en las estudiantes, afectando en su salud psicológica e impactando negativamente en el bienestar de la persona (García-estrada, en proceso).

Como se puede observar, las investigaciones de acuerdo con este tema han sido de suma importancia y relevancia durante la pandemia de COVID-19. La incertidumbre, el miedo y la desesperanza que vive el ser humano ante el nuevo virus ha tenido repercusiones en su estado psicológico, físico y social. Además, el confinamiento perjudicó el sueño de las personas, surgiendo así trastornos del sueño-vigilia, lo cual causó serios problemas de salud; por ello, se recomiendan intervenciones cognitivas conductuales como el control de estímulos para disminuir actividades que promueven la disminución de la vigilia, así como la relajación muscular para brindar una asociación de la persona con su sueño. 


\section{Referencias}

Ahammed, B., Jahan, N., Seddeque, A., Hossain, M. T., Shovo, T.-E.-A., Khan, B., Mamun, M. A., \& Islam, M. N. (2021). Exploring the association between mental health and subjective sleep quality during the COVID-19 pandemic among Bangladeshi university students. Heliyon, 7(5), e07082. https://doi.org/10.1016/j.heliyon.2021. e07082

Álvarez, H., \& Jiménez, U. (2020). Intervención psicológica en trastornos del sueño: una revisión actualizada. Psychology, 11(2), e12-1. https://doi.org/10.5093/cc2020a9

Bornhausen, A., Kessler, R. M. G., \& Gasperin, S. I. (2018). Calidad subjetiva del sueño en cardiopatía isquémica crónica. Insuficiencia Cardíaca, 13(3), 118-124.

Buysse, D. J., Reynolds, C.F., Monk, T. H., Berman, S.R., \& Kupfer, D. J. (1989). The Pittsburgh Sleep Quality Index: A new instrument for psychiatric practice and research. Psychiatry Research, 28(2), 193-213. https://doi.org/10.1016/0165-1781(89)90047-4

Cabrera, E. A. (2020). Actividad física y efectos psicológicos del confinamiento por covid-19. Revista INFAD de Psicología. International Journal of Developmental and Educational Psychology, 2(1), 209-220.

Casagrande, M., Favieri, F., Tambelli, R., \& Forte, G. (2020). The enemy who sealed the world: effects quarantine due to the COVID-19 on sleep quality, anxiety, and psychological distress in the Italian population. Sleep Medicine, 75, 12-20. https:// doi.org/10.1016/j.sleep.2020.05.011

Castillo, J., Lan, A., Morán, J., Aparicio, E., Tuñón, V., Gutiérrez, M., \& Ortega, C. (2020). La relación entre el rendimiento universitario y la privación de sueño. Revista De Iniciación Científica, 6(2), 53-59. https://doi.org/10.33412/rev-ric.v6.2.2896

Cobacango, J., Macías, J. B., Ordoñez, E. M., Palma, A. J., \& Valdiviezo, J. A. (2019). Trastornos del sueño y su influencia en la conducta de los estudiantes. Atlante Cuadernos de Educación y Desarrollo, (agosto). https://www.eumed.net/rev/atlante/2019/08/ trastornos-sueno-estudiantes.html

Contreras, A. (2013). Sueño a lo largo de la vida y sus implicancias en salud. Revista Médica Clínica Las Condes, 24(3), 341-349 https://doi.org/10.1016/S0716-8640(13)70171-8

Espinosa, M., \& Manosalva, I. (2020). Calidad de sueño y actividad fisica en estudiantes universitarios de primer año del área de la salud (Tesis de licenciatura). Universidad del Desarrollo, Chile. http://hdl.handle.net/11447/3818 
Failoc-Rojas, V. E., Perales-Carrasco, T., \& Díaz-Velez, C. (2015). Trastornos del sueñovigilia y calidad del sueño en estudiantes de medicina en Latinoamérica: una realidad preocupante. Neurología Argentina, 7(3), 199-201. https://doi.org/10.1016/j. neuarg.2015.03.004

Fontana, S. A., Raimondi, W., \& Rizzo, M. L. (2014). Calidad de sueño y atención selectiva en estudiantes universitarios: estudio descriptivo transversal. Medwave, 14(08). https://doi.org/10.5867/medwave.2014.08.6015

García-Estrada, L. I (en proceso). Calidad de sueño y estrés en mujeres universitarias durante la pandemia de Covid-19 (Tesis de licenciatura). Universidad de Sonora, México.

González, J. C., Acevedo, G., Alarcón, P. D., Casas, Á. M., Ardila, G., Bernal, J. D., Avella, J. L., \& Pinzón, J. (2018). Prevalencia de trastornos del sueño en niños y adolescentes. Carta Comunitaria, 26(148), 11-18. https://doi.org/10.26752/ccomunitaria.v26. n148.357

Huang, Y., \& Zhao, N. (2020). Generalized anxiety disorder, depressive symptoms and sleep quality during COVID-19 outbreak in China: a web-based cross-sectional survey. Psychiatry Research, 288, 112954. https://doi.org/10.1016/j.psychres.2020.112954

Jiménez-Genchi, A., Monteverde-Maldonado, E., Nenclares-Portocarrero, A., EsquivelAdame, G., \& de la Vega-Pacheco, A. (2008). Confiabilidad y análisis factorial de la versión en español del índice de calidad de sueño de Pittsburgh en pacientes psiquiátricos. Gaceta Médica de México, 144(6), 491-496.

Organización Mundial De La Salud. (2020). Inmunidad colectiva, confinamientos y COVID-19. https://www.who.int/es/news-room/questions-and-answers/item/herdimmunity-lockdowns-and-covid-19

Pinto, J., van Zeller, M., Amorim, P., Pimentel, A., Dantas, P., Eusébio, E., Neves, A., Pipa, J., Santa Clara, E., Santiago, T., Viana, P., \& Drummond, M. (2020). Sleep quality in times of Covid-19 pandemic. Sleep Medicine, 74, 81-85. https://doi.org/10.1016/j. sleep.2020.07.012

Ramírez-Ortiz, J., Fontecha-Hernández, J., \& Escobar-Córdoba, F. (2020). Efectos del aislamiento social en el sueño durante la pandemia COVID-19. [Archivo PDF] https:// doi.org/10.1590/SciELOPreprints.801 
Sierra, J. C., Jiménez, C., \& Martín, J. D. (2002). Calidad del sueño en estudiantes universitarios: importancia de la higiene del sueño. Salud Mental, 25(6),35-43. https://www.redalyc.org/articulo.oa?id=58262505

Velayos, J. L., Moleres, F. J., Irujo, A. M., Yllanes, D., \& Paternain, B. (2007). Bases anatómicas del sueño. Anales del Sistema Sanitario de Navarra, 30, 7-17. 


\title{
Capítulo 6
}

\section{Ensayo sobre la muerte y la COVID}

\author{
Ignacio Alberto Valdez Bernal
}

La reflexión sobre el significado de la muerte en la amenaza de contagio en la pandemia de COVID-19 resulta azarosa, por involucrar precisamente el miedo a contraer una forma letal de la enfermedad que, indiferenciadamente, se cierne sobre toda persona en este momento (Valero et al., 2020).

Tal vez se considere impertinente o políticamente incorrecto, en el contexto de quienes han tenido que padecer de manera cercana todo el proceso de la enfermedad en sus diversas etapas, en la persona de alguien relacionado por lazos de parentesco, amistad o relación significativa.

Sin embargo, el presente escrito pretende plantear algunos de los elementos que se involucran en el tema; sin intención de servir de apoyo afectivo, racional o con el ánimo de aprovechar esta circunstancia de debilidad relativa para la toma de decisiones, presentando algún modelo de respuesta conductual ante el problema (León, 1987); a lo sumo, plantear para quien en este momento aún no ha sido alcanzado por la adversidad en su entorno personal y familiar o en sí mismo; o incluso para quien sí lo ha sido; para retomar algunos elementos que durante toda la vida de un ser humano son motivo necesario e ineludible de consideración (Cabero et al., 2011).

El tema de la muerte como el fin de la vida abarca, en estos dos elementos, todo lo que nos concierne como seres vivientes; siendo ambos conceptos indefinibles tanto por su mera forma de enunciación como por lo complejo de las relaciones y supuestos que implica su consideración en todos los ámbitos del conocimiento 
humano, así como por su análisis reflexivo desde cualquier horizonte cultural o nivel de conciencia que se suponga (Maglio et al., 2016).

La vida como conjunto de fenómenos (manifestaciones sensoriales dotadas de sentido), resultado de algo que puede ser analizado hasta ciertos límites de lo infinitesimal y complejo, es un elemento elusivo a toda consideración. La imposibilidad actual para activar este conjunto de fenómenos (replicado a nivel de isomorfismos mecánicos, electrónicos, digitales, procesuales, entre otros) como algo todavía no logrado, pero susceptible de realizarse con un nivel de desarrollo, que está en ciernes con todas las consecuencias que lógicamente se infieren; nos evita la discusión con sentido acerca de quién da la vida (nótese la trampa del lenguaje), qué sea la vida (toda vez que como toda función del lenguaje nos remite a una imagen sin forma que creemos entender y de la cual hablamos como si efectivamente lo entendiéramos) y, por lo tanto, para los fines prácticos tal consideración es inane (Ardila, 2003; Carrillo, 2007).

En una encuesta realizada en España, con ancianos en edad y condición vulnerable frente a la pandemia, lo que más resaltaban como significativo para sus precarias vidas, repusieron que era la posibilidad de tomar su bebida preferida al cobijo o abrazo de los rayos de sol, desde su ventana en un edificio comunitario, viendo con sorpresa un nuevo día, sentir entre los dedos la finura del pelo de su gato preferido y la posibilidad de tener un lugar donde descansar sus cuerpos, en los que podían reconocer cada una de las debilidades padecidas, algunas de las cuales harían cesar este estatus (Mouzo \& Jan, 2021).

La conciencia o no de la propia existencia, su precariedad, su limitación temporal, el significado o no de la realización de lo que se supone es lo que debe ser es un esquema insalvable (Wyss, 1988). Una sandía puede llegar a ser o no ser, desarrollar unos centímetros, concentración de azúcares, cantidad de semillas, cantidad de agua incorporada, o ser arrojada sin más al montón de los desperdicios por faltar alguno de esos elementos que para la sandía no son (no lo sabemos quizá) algo a lo que pudiera haber aspirado.

La precariedad como falta de seguridad es el factótum, en sentido figurado, como el entrometido imponderable, pero absolutamente presente (siguen las imágenes) en toda la vida, desde la posibilidad de ser engendrado precisamente él y no 
otro elemento celular primordial; su inestable o precisado de atención para no alterar e incluso suspender el proceso de desarrollo de su corporeidad; la separación o nacimiento con diferentes grados de riesgo, que pueden o no corresponder a los niveles de acceso a los servicios de salud o a un involuntario e impredecible fallo de la corriente eléctrica; hasta la suspensión de la vida por la equivocación fortuita de la toma de un fármaco necesario para mantenerla en alguna de las etapas de la vida (Hurtado, 2008; Lindenboim et al., 2000).

La multiplicidad casi imponderable, si no infinita, de formas como puede suspenderse o mantenerse (siguen las imágenes) la propia vida y que depende de los infinitos tiempos, modos, lugares, condiciones (y sigue la lista) en los que se vive. La suspensión o mantenimiento voluntarios o no del proceso de anidación, desarrollo, nacimiento determinado por un acto violento de uno de los progenitores, una mentalidad determinada que anhela o teme el nacimiento del vástago, un accidente vial, una familia que siente que su realización lo representará al perpetuar su línea de parentesco, raza o condición o cualquier cosa (Muñoz, 2009; Puget, 2012).

En las grandes ciudades $-\mathrm{y}$ en las no tanto- es común despertar agradecido por poder ver el nuevo día, sin haber sido alcanzado por las balas de una gavilla o la fuerza del estado que buscan la manera de vivir; el hecho de que la instalación eléctrica del edificio no haya colapsado, provocando un incendio de dimensiones imponderables por las pérdidas humanas; despertar al otro lado de la frontera, en un lugar cercano a donde podrán encontrar refugio y no haber perecido a causa de la deshidratación, la violencia ejercida por grupos de connacionales empleados en saqueo y tráfico de órganos; no amanecer a causa de un alimento descompuesto que fue ingerido sin saberlo (Cuanalo et al., 2006; Varga, 2017).

Anejo al concepto de vida, se da el de salud y enfermedad, con todas sus variantes podríamos decir; aunque impropiamente infinitas y que permiten vivir la vida o sobrevivir en la vida. Despertar con un dolor de cabeza agudo, afectado de la visión y tras una serie agotadora y traumática de movimientos, procedimientos y análisis se descubre que, en el plazo de tres meses, ya no se podrá despertar, si no se somete a un procedimiento agresivo y lesivo quirúrgico, químico o de radiación, con efectos secundarios muy lastimoso; o por el contrario, poder con alegría reconocer que después de hecha una prueba, tras catorce días de síntomas ambiguos, solo 
tenemos (siguen las imágenes) influenza o, en el mejor de los casos, un catarro mal cuidado (Dieguez, 2008; Fuller, 2015).

Esta ineluctabilidad de todo proceso que elude la ley física de la entropía, mientras presenta su calidad de viviente de volver a la fase previa a la que le dotó de esa cualidad, es y ha sido el origen de todas las concepciones culturales respecto a todas las cosas. A través de los siglos, todo hombre que llega al uso de razón se pregunta, entre otras cosas, acerca de la naturaleza del propio ser y su conciencia y, en definitiva, acerca de su inevitable dejar de serlo (Carr, 2010).

La capacidad del ser consciente de esto es el origen de toda explicación racional, acerca de la finitud de todas las cosas y del ser humano y su conciencia, aunque para cualquier mecánico es evidente que un automóvil de último modelo, al cabo del tiempo, será un montón de chatarra, incluidos todos sus circuitos digitales y los programas que lo hacen funcionar (Paramio, 2010).

De allí que, quien tenga la paciencia y curiosidad de explicar lo mismo con lo mismo y de dar respuestas aparentemente lógicas a lo que no lo es tanto, y cuando al final entienda que ante la tumba del autor más destacado por sus construcciones tanto materiales (grandes edificaciones y máquinas o realizaciones políticas o mediáticas que han logrado paliar o transformar el entorno o un gran entorno) como de índole no tangible, pero sí inteligible (matemáticas de avanzada, explicaciones del ser del universo, las estructuras complejas e hipercomplejas, líquidas y en constante transformación de la física que augura un mundo imposible de prever), no fueron capaces de salvarlo de convertirse en un montón de ceniza o, en un caso más irónico, en un órgano diseccionado y que habita por no se sabe cuánto tiempo un frasco de laboratorio.

Cuatro grandes tipos de gurúes han asumido históricamente enfrentar este impasse, los poetas y artistas, los filósofos, los fundadores de religiones y los autodenominados científicos, con igual suerte, lo que nos permite visualizar en cada uno de estos caminos un desesperado y desesperante deseo de entender y la dificultad de poder explicar.

En los poetas y artistas, se da por la conversión de lo observado en un elemento plástico o la utilización de imágenes, sonidos u otros medios, que parecen hacernos sentir a través de la experiencia un significado oculto y perceptible a través de la 
imaginación, la obnubilación de los sentidos o el entendimiento con la ayuda o sin ella de inductores, un grado de sensibilidad que roza con lo extático y que pretende la expansión, la purificación, la sublimación de lo que aparece simplemente ante nosotros.

En los filósofos, se manifiesta en todas las formas una necesidad de negar el infausto destino de la vida del humano, buscando una verdad que dé cuenta de una alternativa válida para la vida y que termina en algo parecido a lo que plantea Heidegger, quien ha podido hacer del ser-para-la-muerte (así lo escribe, pero en alemán) la característica denotativa del hombre auténtico (no había distinción de género en el concepto abstracto del ser humano), quien vive su contingencia, su finitud, su limitación; pues sabe que con la muerte termina todo, se anticipa a ella, y da sentido real a cada instante que vive, de tal manera que resulta la única ventana abierta frente a la conciencia de que la muerte es siempre la propia muerte; frente a esta, no hay preparación o experiencia que impida que reaccionemos con angustia, pues, para este autor como para Sartre, la angustia es el sentimiento o la tonalidad afectiva que nos embarga cuando nos enfrentamos a la nada (Kübler-Ross \& Jáuregui, 2008).

En los fundadores de religiones, se da una formulación que se basa en un planteamiento que da por supuesta o no una realidad que rebasa el carácter físico (en el sentido que lo entendemos ordinariamente), pues no somos capaces mientras estemos en cuerpo (salvo experiencias muy determinadas) de percibirla sino a través de una actitud o forma de comprensión alterna, fundada en lo que se denomina la fe en los supuestos básicos del fundador y los intentos de comprensión y explicación que darán sus seguidores que pueden ser o no disímbolos. Ordinariamente (no en todos), se habla de la necesidad de observar determinado tipo de conducta o moral, fundada en una ética conforme con los supuestos mencionados, sin la cual no existirá la posibilidad de trascender; esto es, continuar viviendo en una forma de vida alterna inimaginable después de la muerte, que representaría como un nuevo nacimiento con suerte diferente para el observante y el no observante o, en algunos casos, con una fusión con el cosmos que no puede ser comprensible.

En los científicos, el conocimiento (scientia = saber, conocimiento) que, tradicionalmente, hacía coincidir a la representación con sentido en el individuo de la 
realidad percibida por los sentidos (adaequatio intellectus et rei), es sustituido por la noción de validez, que corresponde a la adecuación a determinadas reglas para su aceptación, con lo que las reglas determinan la comprensión de los objetos y realidades del mundo, que dejan fuera como inválidos a aquellos que no son verificables, contrastables y reductibles a unidades, generalmente de medida o significado, dentro de un conjunto de elementos del mismo conjunto. Así que la muerte entra en un conjunto vacío, como gran parte de las cosas de este mundo o de otro, si lo hubiera.

Habida cuenta de que nuestro concepto de muerte es inasible, ya que el mismo adagio popular plantea que no es necesario temerle, pues, mientras nosotros vivimos, ella no está y, al morir, ya no estaremos; sin embargo, no nos permite evadirlo como un hecho de vida (curiosa incongruencia), que señala y marca el fin de esta.

El problema central de la pandemia de COVID-19 sigue siendo el efecto de la siniestralidad, que es magnificado no sin razón, aun cuando el porcentaje en comparación con los pacientes afectados corresponde, eso sí, a la suma de los que son resultado de los datos de las razones ordinarias de fallecimiento (Cirera et al., 2020).

El hecho de su concentración estadística hacia los grupos de población vulnerable, tanto por la edad como por la presencia de enfermedades degenerativas o resultado de mal funcionamiento, abuso o ausencia de atención a regímenes básicos y necesarios que lo evitarían, no permite apartar la vista de los casos particulares presentados por razones imponderables de falta de atención a tiempo, al presentarse o no los síntomas; considerando la dispersión geométrica de personas afectadas a partir de un solo portador, incluso asintomático, o el contagio obtenido por contacto con materiales inertes en los que se depositó el virus (Villerías \& Juárez, 2020).

En relación a la afectación de personas de tercera edad que, casi ordinariamente, portan los factores que los hacen vulnerables de manera significativa, no solo ante el virus COVID sino ante cualquier grupo de agentes biológicos que causan enfermedades en circunstancias parecidas o no a las del virus en cuestión; es importante resaltar un elemento que hace aumentar la angustia ante un desenlace fortuito, pero probable, en comparación con otras afecciones posibles, esto es: el conjunto de eventos y condición fisiológica y orgánica que, de atenderse, paliarán los síntomas concomitantes, pero casi con seguridad conducirán a un nivel de cuasi irreversibilidad; dado que no se poseen aún medicamentos o procedimientos que 
nulifiquen al virus o sus efectos, y separarán al paciente de su contexto familiar; así, con una certeza estadística de casi el 70\%, culminará en el fin de la vida de la persona (Chainé et al., 2020).

Existen algunos estudios de personal médico o paramédico, que han reportado y analizado los eventos estadísticamente o mediante una sistematización de los diferentes niveles de estrés, calidad o falta de ella, por la imposibilidad generada por la gran cantidad de afectados que probablemente encontraron fortuitamente una cama de atención a los síntomas más extremos de las fases iniciales; como de la casi imposibilidad de revertir los efectos de la afección en el momento en que el paciente es intubado, para someterlo a una atención de apoyo cuasi mecánico, en la que poco más puede hacerse y en el cual las enfermedades o deficiencias orgánicas en el paciente terminan con él (Muñoz \& Giraldo, 2021).

Uno de los elementos que puede resaltarse es que las personas se preocupan considerablemente por el proceso de morir tanto como por la muerte en sí. En quedar de un golpe separados de toda su vida, tal como se ha vivido en una especie de muerte previvida, en la que es despojado de todos sus haberes, saberes e ilusiones irreversiblemente. La forma concreta en que se manifiesta es que su mundo familiar, de amistades de enemistades, es decir, su razón de ser, se transforma en el ámbito de un hospital (en el mejor o peor de los casos), rodeado de máscaras y batas con un respirador artificial y la imposibilidad de poder llevar a cabo las actividades físicas o biológicas más básicas por su postración y dependencia del instrumental de apoyo.

El paraíso perdido, para las personas de este grupo de edad, resulta tan inocente y angustiante como el hecho de que el tiempo restante es extremadamente corto; en este, rodeando a la necesidad de sobrevivir por la acción mecánica de un hilo de vida, es imposible ya disponer de un tiempo relativa o absolutamente más largo, en el que el tiempo transcurra lento, en medio de la dificultad y fatiga que dan los años y las afecciones, pero que cada más o menos espaciado, la familia o los amigos o conocidos puedan venir a visitarlo, compadecerse a sí mismos al verle en condiciones a las que naturalmente pensarán llegar, que puedan tomarle de la mano, decirle lo bien que se ve y ese tipo de cosas. En palabras de expertos en el fenómeno de la muerte, el coronavirus desafía algunos de nuestros supuestos sobre el proceso de morir (Alejandre et al., 2020). 
Tan importante como el desafío a los supuestos sobre el proceso de morir aparece, por lo menos para los vivos, la necesidad de revisar los supuestos sobre el proceso de vivir; la sociología, la demografía y la política tratan de soslayarlo, toda vez que la simple descripción en estos campos es en la actualidad algo políticamente incorrecto; al subrayar los hondos abismos de diversidad, de condición, de compartir los bienes naturales y culturales, la destrucción sistemática de recursos, los nacionalismos y propiedad sobre recursos y problemas derivados como la migración forzada, la muerte por epidemias o hambruna generalizada y un enorme etcétera; lo que se da a ver es, por un lado, una concentración absurda y, por el otro, una condición sin nombre.

La psicología y la filosofía al intentar encontrar o dar sentido, a pesar de esta condición que resulta ser global, tienen dos caminos aparentemente: privilegiar y justificar el confort perdido y reclamado por uno de los grupos; o lo que es peor, la receta de la resiliencia entendida muy elementalmente como la capacidad que tiene una persona para superar circunstancias traumáticas como la muerte de un ser querido, un accidente; esto es, superar la adversidad (que en el caso de las condiciones de la globalidad planetaria es su condición como hecho); o la necesidad de abrir la ventana propuesta por Heidegger para quien cumple con su naturaleza de persona auténtica (hombre auténtico) al vivir su contingencia, su finitud, su limitación; pues sabiendo que con la muerte termina todo, se anticipa a ella y da sentido real a cada instante que vive. Una tercera opción no es propiamente un camino, sino el fin de él, asumir la condición humana en el sentido de Sartre: vivir conscientemente en la angustia como el sentimiento o la tonalidad afectiva que nos embarga estando enfrentados a la nada (Suárez- Ruíz, 2021).

Como seres vivientes regidos por la neguentropía, en que la vida es la constante necesaria que mantiene alejado al caos, que es el estado más probable de las cosas, y hacia el cual la entropía nos impulsa constantemente; somos compelidos a buscar hacer coincidir nuestro actuar y pensar en la conservación del orden, que es condición necesaria para la subsistencia del sujeto (vivir) y una subsistencia que responda al orden necesario para mantener en equilibrio el conjunto de subsistemas, cuya disfunción es la enfermedad (Leff, 2010). 
En este orden de cosas, lo más importante resulta intentar vivir la vida de manera auténtica, aunque sea como una vida con salvavidas, pues de la misma forma que en la resiliencia, se aprende a vivir en la adversidad de la mejor manera posible; el cómo dar sentido real a cada instante vivido ¿es el reto?

Al considerar los niveles fluctuantes y por demás crecientes del número de gente infectada, así como la inhabilitación y muerte de personas cada vez más cercanas al grupo, nos hace comprender y realizar nuestra propia vida, dándole sentido de muy diversa manera; pero, al ver amenazada nuestra propia seguridad ¿cómo superar la adversidad? (de Faramiñán, 2020).

La huida y la distracción dispersiva ocupada en los entes intermundanos y la fortuita caída, en aquello a lo que se huye por ese mismo hecho, es una salida socorrida por las personas que, ante la ineludible solución de su situación de angustia en el no-ser, no ven gran diferencia en su condición actual de vivir de manera inerme ante todos los males posibles; desde un asalto en la unidad de transporte, la adquisición de una enfermedad letal por alimentos corrompidos o la falla en una válvula de la cocina; a la posibilidad de sacar el diario y refugiándose en el recinto que sirve de hogar... por esta vez... que puede ser la última.

El escenario alterno es aquel para quien vivir de la mejor manera posible en la adversidad es preocuparse de la manera de que no se infectaran al ingresar al gimnasio de manera clandestina, o cómo lograr andar en bicicleta sin la debida protección reclamada y eludiendo un posible contacto con quien pudiera hacérselo ver o impedirle hacerlo. El dar sentido real a cada instante vivido es poder, en condiciones de no recurrir a los rituales de higiene y apariencia establecidos en las relaciones en persona y verificar y tener la conexión necesaria para realizar las tareas que los mantienen unidos a su fuente de ingresos de forma sincrónica o asincrónica y sí, la huida y la distracción dispersiva en los entes intermundanos con la fortuita o muy segura salida definitiva de lo que es estar aquí.

Y muchos cuasi infinitos escenarios en los cuales el ser viviente del género humano vive su corto, pero muy personal momento-instante de eternidad en el universo.

Esto es gratificante pese a su aparente nimiedad, el haber sido una porción infinitesimal de materia, pero materia consciente que de una u otra manera ha in- 
corporado a sí misma un reflejo mediado por las capacidades alcances y límites de los órganos de contacto como son los sentidos; un adecuado modelo isomórfico de todo lo que le ha rodeado en un espacio-tiempo bien definido, pero con capacidad de estar siempre abierta a un autocompletarse y re-flexionar sobre el propio modelo.

Desde la caña pensante cartesiana hasta el creador de mecanismos, que imitan y re-producen creativamente en función de los mecanismos ideados y con un modelo que se autorreplica y completa en forma diferente que emula a su artífice; el ser humano pierde cada vez que uno de sus átomos del cuerpo que en el tiempo ha constituido la humanidad, se extingue. Nunca más ha vuelto a existir, nunca del mismo modo, nunca en condiciones similares; sin embargo, su finalidad ha sido cubierta (Patton, 2021).

Es tentativa la imagen de este Leviatán, para el que el conglomerado humano a través de los tiempos ha permitido la efímera existencia de los individuos de toda ralea y posición en el cuerpo; que se reproduce y expande en cada uno de sus representantes y re-creaciones que integran en su bagaje genético y en su tendencia a lo cada vez más complejo y diverso el significado de la vida en colectivo.

La propia vida, la limitada e irrepetible vida personal, en el mar inmenso de todas las personas que han vivido en el espacio-tiempo de lo humano, haga lo que haga es parte del cimiento, de la estructura de la techumbre, de lo que en conjunto es la arquitectura de la vida. Habrá por ello que lamentarse, indignarse o imaginar que es solo el barrunto de otra realidad, de la que esta es solo el espejo deforme de lo inconmensurable e inimaginable; que en términos filosóficos, teológicos o poéticos o científicos de otra nueva índole, los cuatro permitan a quien se encuentra dominado por la angustia, como sentimiento o tonalidad afectiva que nos embarga cuando nos enfrentamos a la nada, dar cuenta fiable y, si no tangible, cuanto intuible, de que la conciencia sin soporte es indestructible; la certeza de lo que se espera, la convicción de los que no se ve; la puerta abierta a un mundo inimaginable; el punto final hacia el que todos los esfuerzos y anhelos todos pudieran orientarse. 


\section{Referencia}

Alejandre, S. N., Ortiz, M. J., \& Prieto, A. (2020). Restauración ecológica en tiempos de covid-19, ¿solución o desafío? (Revisión). Roca. Revista científico - Educacional De La Provincia Granma, 17(1), 130-142. https://revistas.udg.co.cu/index.php/roca/article/ view/2141

Ardila, R. (2003). Calidad de vida: una definición integradora. Revista Latinoamericana de Psicología, 35(2), 161-164.

Cabero, J., Marín Díaz, V., \& Infante, A. (2011). Creación de un entorno personal para el aprendizaje: desarrollo de una experiencia. Edutec. Revista Electrónica De Tecnología Educativa, (38), 1-13. https://doi.org/10.21556/edutec.2011.38.380

Carr, E. H. (2010). ¿Qué es la historia? Ariel.

Carrillo, J. R. (2007). Influencia de la Estética en los objetos virtuales (Tesis doctoral). Universitat de Barcelona.

Chainé, S. M., Montoya, A. L., Maldonado, A. B., Aguirre, A. B., García, R. R., Rosales, F. L., \& Cáceres, C. F. (2020). Condiciones de salud mental durante la pandemia por COVID-19. Revista internacional de investigación en adicciones, 6(2), 11-24.

Cirera, L., Segura, A., \& Hernández, I. (2020). Defunciones por COVID-19: no están todas las que son y no son todas las que están. Gaceta Sanitaria, 35(6), 590-593. https:// doi.org/10.1016/j.gaceta.2020.06.006

Cuanalo, O. A., Quezada, P., Aguilar, A., Olivan, A. M., \& Barona, E. (2006). Sismos y lluvias, factores detonantes de deslizamientos de laderas en las regiones montañosas de Puebla,México.e-Gnosis, (4),1-14.https://www.redalyc.org/articulo.oa?id=73000413

de Faramiñán, J.M. (2020). Aspectos jurídicos del estado de alarma y la pandemia COVID-19. Revista Estudios Jurídicos. Segunda Época, 1(20), 473-553. https://revistaselectronicas. ujaen.es/index.php/rej/article/view/5927

Diéguez, A. (2008). ¿Es la vida un género natural? Dificultades para lograr una definición del concepto de vida. ArtefaCToS, 1(1), 81-100. https://revistas.usal.es/index.php/ artefactos/article/view/17/16

Fuller, P. (2015). Sobrevivir, existir, vivir: la terapia en cada fase de la psicosis grave. Herder Editorial. 
Hurtado, D. R. (2008). Corporeidad y motricidad: Una forma de mirar los saberes del cuerpo. Educação \& Sociedade, 29(102), 119-136. https://doi.org/10.1590/s010173302008000100007

Kübler-Ross, E., \& Jáuregui, P. (2008). La muerte: un amanecer. Luciérnaga.

Leff, E. (2010). Imaginarios sociales y sustentabilidad. Cultura y Representaciones Sociales, 5(9), 42-121.

León, O. G. (1987). La toma de decisiones individuales con riesgo desde la psicología. Estudios De Psicología, 8(29-30), 79-94.

Lindenboim, J., Serino, L., \& González, M. (2000). La precariedad como forma de exclusión. Ponencia presentada en el Simposio "El Cono Sur y su inserción en el Tercer Milenio", Buenos Aires, Argentina.

Maglio, I., Wierzba, S. M., Belli, L. F., \& Somers, M. E. (2016). El derecho en los finales de la vida y el concepto de muerte digna. Revista Americana de Medicina Respiratoria, 16(1), 71-77. https://www.redalyc.org/pdf/3821/382144644009.pdf

Mouzo, J., \& Jan, C. (2021). Las personas de mayor edad son las que menos miedo tienen a morir por covid, según el CIS. El País. https://elpais.com/sociedad/2021-03-04/ las-personas-de-mayor-edad-son-las-que-menos-miedo-tienen-a-morir-por-covidsegun-el-cis.html

Muñoz, M. C. (2009). La importancia de la colaboración familia-escuela en la educación. Innovación y Experiencias educativas, 16, 1-9.

Muñoz, S. A., \& Giraldo Builes, D. E. (2021). Características epidemiológicas del paro cardíaco extrahospitalario atendido por los servicios de emergencias médicas en la ciudad de Medellín, entre los años 2018-2019. Estudio de corte transversal. http://hdl.handle. net/10495/20284

Paramio, L. (2000). Decisión racional y acción colectiva. Leviatán, 79, 65-83.

Patton, K. T. (2021). Estructura y función del cuerpo humano. Elsevier.

Puget, E. M. (2012). Poderes públicos y mediación familiar. En E. Souto (Coord.), Mediación Familiar (pp. 307-349). Dykinson.

Suárez-Ruíz, E. J. (2021). Medio ambiente, medios de comunicación y psicología moral. Sobre el potencial de la convergencia disciplinaria en una bioética animal postpandemia. Revista de Bioética y Derecho, (52), 265-286. 
Valero, N., Vélez, M., Duran, A., \& Portillo, M. (2020). Afrontamiento del COVID-19: estrés, miedo, ansiedad y depresión. Enfermería Investiga, 5(3), 63-70. https://doi. org/10.31243/ei.uta.v5i3.913.2020

Vargas, M. (2017). En la frontera, un refugio para la cultura. Cuadernos de Coyuntura, (1), 57-60.

Villerías, I., \& Juárez, M. D. C. (2020). México: las enfermedades crónico-degenerativas (diabetes melitus e hipertensión) y la vulnerabilidad ante el COVID-19. Posición, 1-15. https://www.researchgate.net/publication/341625708

Wyss, D. (1988). La conciencia onírica. Revista de filosofía de la Universidad de Costa Rica, 26(63-64). 
Qartuppi, S. de R.L. de C.V. está inscrita de forma definitiva en el Registro Nacional de Instituciones y Empresas Científicas y Tecnológicas (RENIECYT) con el número 1600052.

Qartuppi, S. de R.L. de C.V. es miembro activo de la Cámara Nacional de la Industria Editorial Mexicana (CANIEM) con número de registro 3751.

Esta obra se terminó de producir en diciembre de 2021.

Su edición y diseño estuvieron a cargo de:

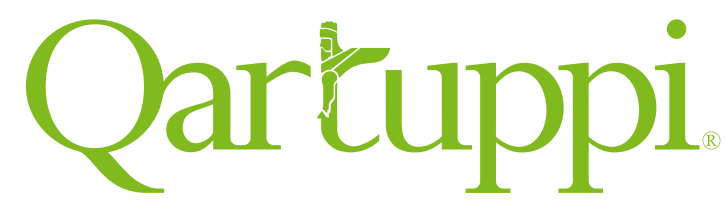

Qartuppi, S. de R.L. de C.V. http://www.qartuppi.com 
Los tiempos de la COVID-19 trajeron consigo transformaciones en la convivencia social, las actividades laborales y escolares, así como aprendizajes desde lo colectivo a la individualidad. Esta obra incluye una visión general de los comportamientos inter e intrapersonales, derivados de las limitaciones en la actividad humana, dadas las políticas públicas de salud a raíz de la pandemia.

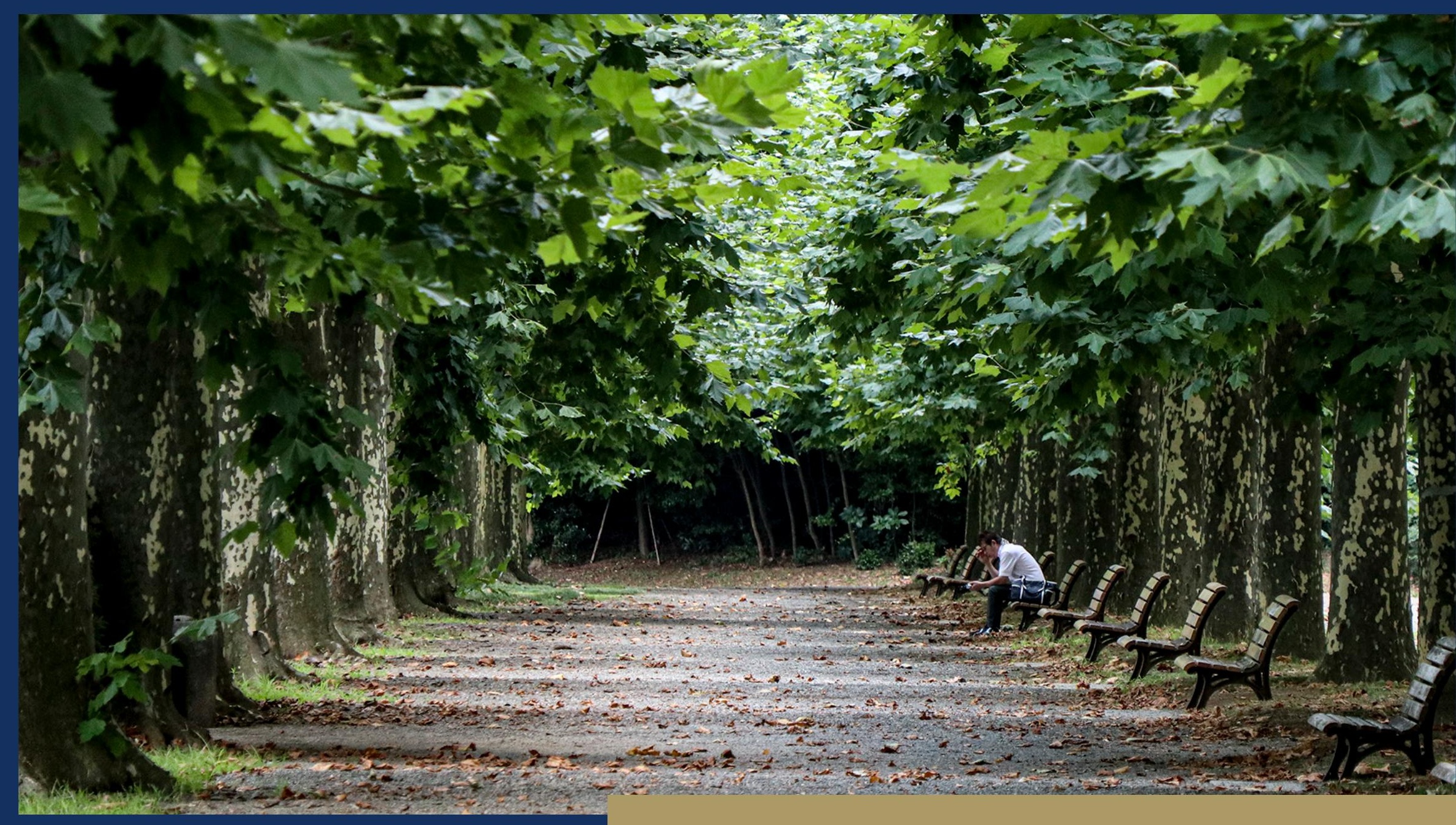

ISBN 978-607-8694-24-2

DOI 10.29410/QTP.21.22
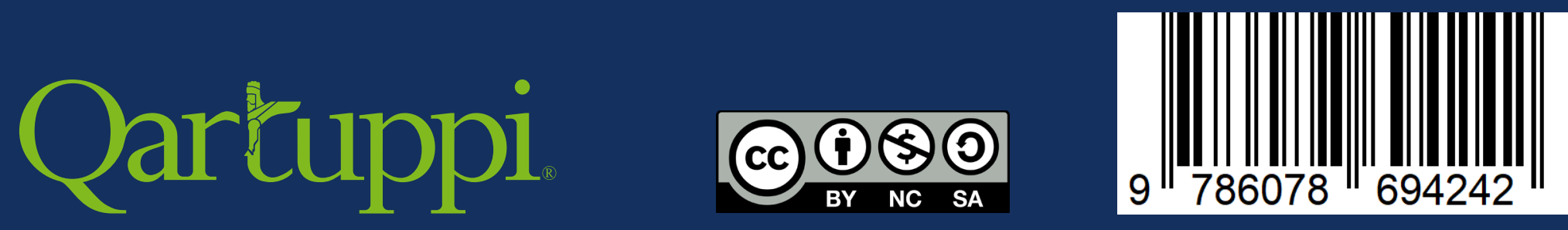